\title{
The Statistical 0ptimization of Indirect Electrochemical Oxidation Process for the Treatment of Dye from Simulated Textile Discharge
}

\author{
*Hajira Tahir, Abdul Rauf Shah, Sonia Iqbal and HM Kifayatullah \\ Department of Chemistry, University of Karachi, Pakistan
}

Submission: April 05, 2017; Published: April 18, 2017

*Corresponding author: Hajira Tahir, Department of Chemistry, University of Karachi, Pakistan, Email: hajirat@uok.edu.pk

\begin{abstract}
The current study focuses the removal of dye by indirect electrochemical oxidation process (IOP). The IOP system was adopted to analyze the operational parameters for the removal of dye from simulated effluent system. The dye Reactive red 120 (RR120) was selected as simulated system because it is extensively used during the textile operations. The operational factors [Dye], [NaCl], $\mathrm{pH}$ and reaction time were selected. The RR120 was proceeded by IOP system in the presence of graphite electrodes and NaCl electrolyte. The Central composite design (CCD) based study was preceded and optimum factors level were identified for treating effluent. Moreover under the optimum conditions by CCD model design about $91 \%$ color and $87 \%$ COD removal were observed. The experimental results are statistically analyzed and mathematically modeled through response surface methodology (RSM). The statistical method of relevance showed the high coefficient of determination value about $\left(\mathrm{R}^{2}=0.7691, \mathrm{R}^{2}=0.3575\right.$ for $\%$ color and \% COD removal, respectively. UV- visible, and FTIR spectrum shows the complete decolorization of dye. The Kinetic study was performed to determine the order of the reaction. The treatment of simulated dye effluent showed that dye is degraded by the indirect electrochemical oxidation process effectively compared to direct oxidation method.
\end{abstract}

Keywords: Indirect Electrochemical Oxidation; Reactive red 120; Color; COD; CCD; FTIR

Highlights

i. The removal of RR120 dye by indirect electrochemical oxidation process was carried out.

ii. The central composite design based study to found optimum levels of factors for maximum responses.

iii.General Mechanism of indirect electro-oxidation process.

iv. Kinetic and cost analysis of indirect oxidation process.

\section{Introduction}

In recent years, there has been increasing interest in finding innovative solutions for the effective removal of contaminants. The presence of dyes, pesticides, detergents, drugs, oil and, soap in the effluent causing water contamination [1]. Moreover textile industries consume extensive volume of water is discharges [2]. The mechanical and wet processes in textile industry uses water, solvent and liquefied ammonia. Whereas the dyes and supporting electrolytes are the main ingredients in textile industries and the discharges of such industrial wastewater contain dyes and electrolytes. It was reported that the primary water consumption about (80-100 $\mathrm{m}^{3} /$ ton of finished textile) and waste water discharge contain (115-175 kg of COD/ton of finished textile [3]. Whereas the textile effluent bearing different compositions in term of color and chemicals [4,5]. The main components of textile effluent come from dyeing and culminating processes and the composition of discharge has different nature they contain high suspended solids, chemical oxygen demand, heat, colour, acidity, and other soluble substances [6]. So the high level demand of textile products has caused a major problem of pollution. The textile discharge due to color prevents the so it is harmful for aquatic bio ecosystem [7]. Azo dyes are the major pollutants in textile wastewater (Figure 1). 


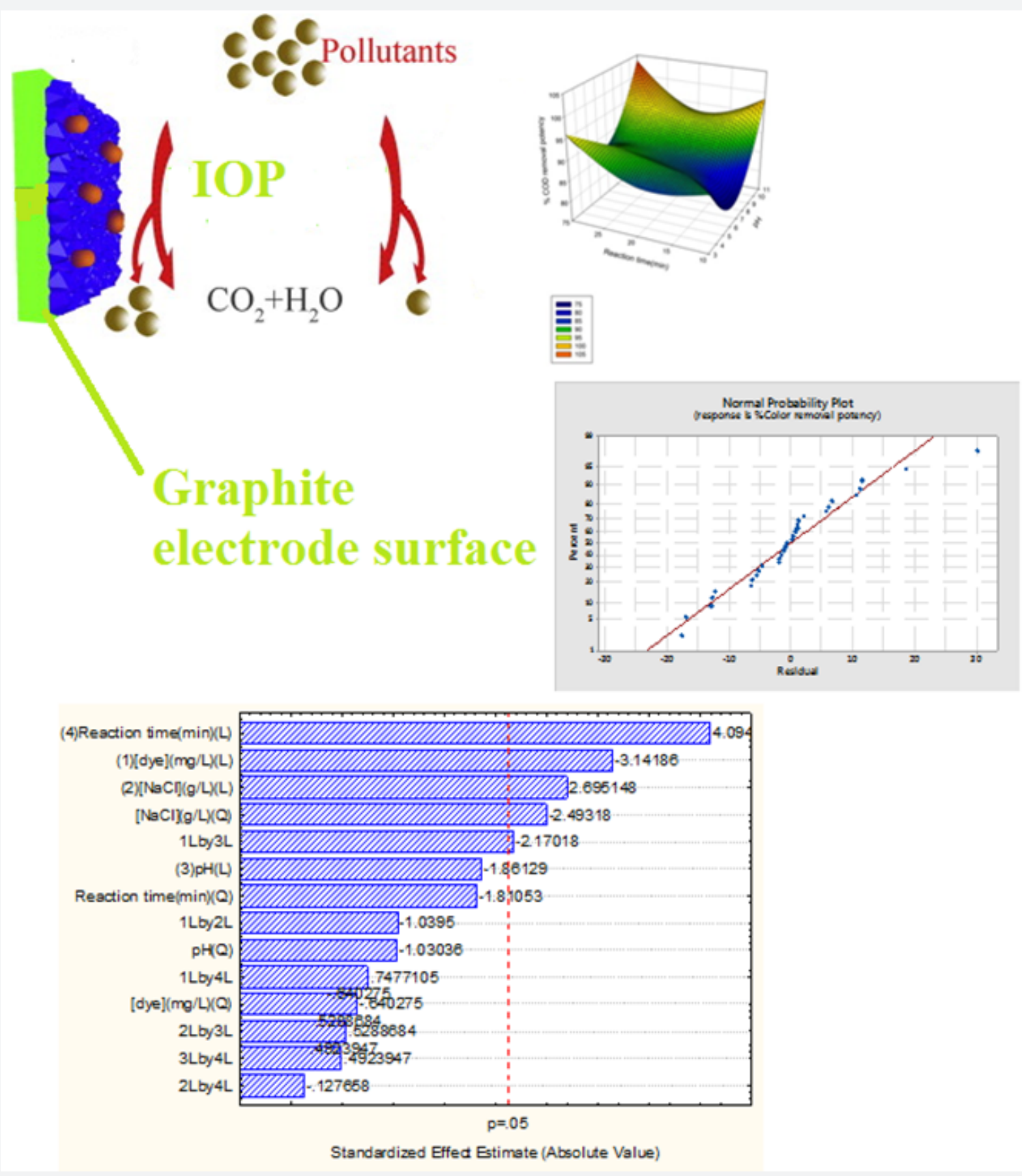

Figure 1: Graphical abstract.

About 50\% among annually world engendered dyes $(700,000 t)$ are azo dyes. About $15 \%$ of the total world engenderment of dyes is disoriented during textile dyeing which is relinquished in effluent [8]. They are non biodegradable due to high stability and azo linkage. The stability of the dye molecule is due to presence of number of aromatic rings around the azo linkage [9]. Moreover the chemical structure of an azo dye molecule effect its application like dye fixation to fabrics. They have low fixation to fabrics so they are disoriented in textile discharges [10]. Subsequently in recent years, it was emphasize to treat effluent before release. Various techniques including adsorption, biological oxidation, and coagulation process are widely utilized to treat the effluent. Furthermore, the above mentioned methods discharge considerable quantity of sludge, which itself requires treatment. Additionally the different composition of textile effluent failed the practical applicability of these methods [11-13]. Consequently the electrochemical processes depend on electrical parameters including voltage 
and current. Therefore by applying these processes the pollutants could be abstracted efficaciously. Chlorine has been efficaciously employed for the treatment of industrial discharge $[14,15]$. The librated chlorine is directly utilized as generated by the indirect oxidation process (IOP). It was reported the $1 \mathrm{~mol}$ of chlorine molecule generates $1 \mathrm{~mol}$ of nascent oxygen as shown in equation below:

$$
\mathrm{Cl}_{2}+\mathrm{H}_{2} \mathrm{O} \rightarrow 2 \mathrm{HCl}+[\mathrm{O}](1)
$$

Moreover it has been successfully utilized to treat the effluent to remove color, odors, cyanide, phenols, detergents etc. and also advantageous to destroy germs [16,17]. The electrochemical oxidation processes are operated under atmospheric conditions so they can be utilized to treat industrial effluents $[18,19]$. At industrial scale they were applied to treat waste water, including Kraft mill, textile, tannery and dye waste [20-23]. Furthermore the direct and indirect oxidation process is effectively employed to degrade the pollutants. Moreover in direct oxidation process pollutants are adsorbed at the electrode surface which resulted the oxidation of molecule due to redox reaction. The indirect oxidation process, $\mathrm{HOCl} / \mathrm{Cl}_{2}$ and $\mathrm{H}_{2} \mathrm{O}_{2}$ are electrochemically engender $[24,25]$. They are highly reactive and cause degradation of pollutants [26,27]. Moreover the process relies on the EC generates oxidizing species such as hydroxyl radical $(\mathrm{OH} \bullet: 2.80 \mathrm{eV})$, chlorine $\left(\mathrm{Cl}_{2}: 1.36 \mathrm{eV}\right)$, hypochlorite (OCl$: 1.72 \mathrm{eV})$, ozone $\left(\mathrm{O}_{3}: 2.07 \mathrm{eV}\right)$, and hydrogen peroxide $\left(\mathrm{H}_{2} \mathrm{O}_{2}: 1.76\right.$ $\mathrm{eV}$ ), which can then be used to decompose dye molecule in the solution.

The indirect oxidation processes mainly produce electro generated oxidized species (EOS) from $\mathrm{H}_{2} \mathrm{O}$ and discharged at the electrodes [28]. It is more efficient and extensively utilized process for the decontamination of waste. Moreover it was also describe that the indirect oxidation process can be summarized by two approaches including electrochemical conversion and combustion. The mechanism of indirect electrochemical oxidation has been suggested that, $\mathrm{H}_{2} \mathrm{O}$ is electrolyzed by anodic catalysis to engender physically physisorbed hydroxyl radicals as represented in equation 2 .

$$
\mathrm{MO}_{\mathrm{X}}+\mathrm{H}_{2} \mathrm{O}--------->\mathrm{MO}_{\mathrm{X}}[\bullet \mathrm{OH}]+\mathrm{H}^{+}+\mathrm{e}^{-}
$$

The physisorbed $\bullet \mathrm{OH}$ formed are chemisorbed by active oxygen.

$$
\mathrm{MO}_{\mathrm{x}}[\bullet \mathrm{OH}]-------->\mathrm{MO}_{\mathrm{x}} \mathrm{O}+\mathrm{H}^{+}+\mathrm{e}^{-}
$$

The hydroxyl radicals or the chemisorbed active oxygen will react with the organic matters $(\mathrm{R})$ represented as :

$$
\begin{aligned}
& \alpha \mathrm{MO}_{\mathrm{x}}[\bullet \mathrm{OH}]+\mathrm{R}-------->\alpha \mathrm{MO}_{\mathrm{x}}+\mathrm{mCO}_{2}+\mathrm{nH}_{2} \mathrm{O}+\mathrm{xH}_{2} \mathrm{O}+\mathrm{ye}- \\
& -(4) \\
& \mathrm{MOXO}+\mathrm{R}---------->\mathrm{MO}_{\mathrm{X}}+\mathrm{RO}-
\end{aligned}
$$

Meanwhile, in the presence of chloride ion, another vigorous oxidant of hypochlorous acid are engendered on the anode during electrolysis and will react with organic matters as represented in equation (6) and (7) [29,30].

$$
\begin{aligned}
& \mathrm{H}_{2} \mathrm{O}+\mathrm{Cl}^{-}-------->\mathrm{HClO}+\mathrm{H}^{+}+2 \mathrm{e}^{-}-----------(6) \\
& \mathrm{HClO}+\mathrm{R} \text {--------->> Product }+\mathrm{Cl}^{-} \text {------------(7) }
\end{aligned}
$$

Various industrial wastes contain substantially giant amounts of chloride ions, by indirect electrochemical oxidation method with active chlorine act as a very felicitous technique to treat such type of effluent. The indirect electro-oxidation process is represented by reactions equation (8-10) [31-33].

$$
\begin{aligned}
& 2 \mathrm{Cl}^{-}----\cdot---->\mathrm{Cl}_{2}+2 \mathrm{e}^{-}-\cdot--\cdot-\cdot-\cdot-\cdot----(8) \\
& \mathrm{Cl}_{2}+\mathrm{H}_{2} \mathrm{O}---------->\mathrm{ClO}^{-}+\mathrm{Cl}^{-}+\mathrm{H}^{+} \\
& \text {Dye + } \mathrm{ClO}^{-}---------->\text {Dye intermediate ---------> } \mathrm{CO}_{2}+\mathrm{H}_{2} \mathrm{O} \\
& +\mathrm{Cl}^{-}-\cdot---------(10)
\end{aligned}
$$

The present study examines the indirect electrochemical oxidation of Reactive red120 using graphite electrodes. The optimization of efficacious parameters in dye abstraction efficiency such as initial dye concentration, electrolyte concentration, initial $\mathrm{pH}$ and reaction time were chosen as response. The Response surface methodology (RSM) is essentially a particular set of mathematical and statistical approach for designing experiments and evaluating the effects of variables, and also finds out optimum conditions of variables to achieve maximum responses [34-36]. Moreover this technique is also helpful for the optimization of variables and utilizes them for the removal of dye by EC process [37-42]. In order to establish the interaction effect of variables, full-factorial central composite design (CCD) was acclimated to optimize the variables for the EC process. The present study focuses the optimize operational parameters for color and COD abstraction from waste discharge.

\section{Materials and Methods}

\section{Sample}

The Reactive red120 was removed from simulated effluent. The structure of it is shown in (Figure 2). Moreover the chemicals used during the IOP (indirect oxidation process) were of analytical grade including $\mathrm{NaCl}, \mathrm{NaOH}$ and $\mathrm{H} 2 \mathrm{SO} 4$. The absorbance measurements were carried out by UV-Vis Spectrometer T80 UV/VIS. As a power supply, by digital DC power supply (Yaxun 1502DD; 15V, 2A) is used to perform EC experiments. The $\mathrm{pH}$, conductance, TDS were measured by (Portable pH/EC/TDS/Temperature HANNA, H19811-5).A $78 \mathrm{HW}-1$ serial constant-temperature magnetic pug mill stirrer is used to perform agitation of the solution during indirect oxidation process. Graphite electrodes were used to perform IOP process. The distance between anode and cathode was maintained at $3 \mathrm{~cm}$. Whereas FTIR model NICOLET 67000 was used to study the structural functional groups of RR120 dyes. For $\mathrm{pH}$ adjustment were maintained by $\mathrm{NaOH}$ and $\mathrm{H}_{2} \mathrm{SO}_{4}(10 \%)$ solutions (Figure 2). 


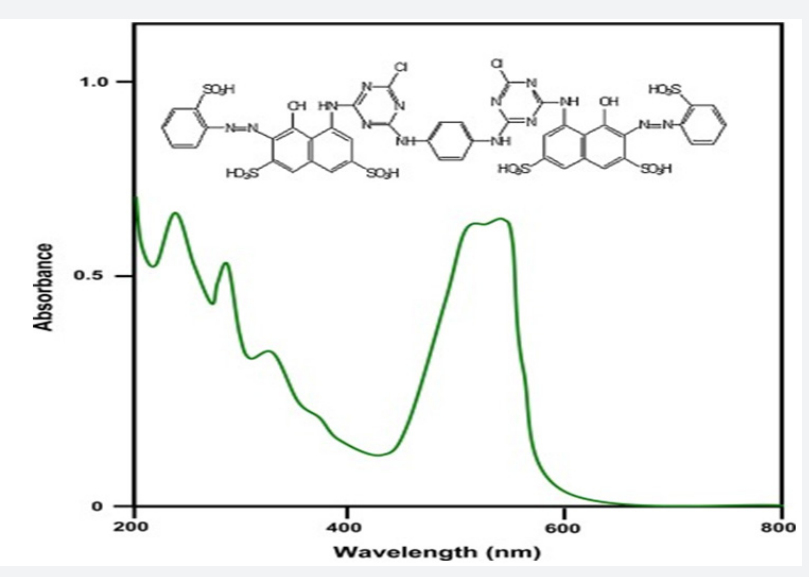

Figure 2: Characteristics of Reactive red 120 dye $\left(\mathrm{C}_{44} \mathrm{H}_{24} \mathrm{Cl}_{2} \mathrm{~N}_{14} \mathrm{O}_{20} \mathrm{~S}_{6} \mathrm{Na}_{6}\right)$

\section{Indirect Oxidation Process(IOP) Setup}

The (IOP) process was preceded in a glass EC reactor consists of graphite electrodes which are immersed in RR120 dye solution. The conductance, $\mathrm{pH}$ and TDS were measured by a pH meter (Portable pH/EC/TDS/Temperature HANNA, H198115). The electrodes are connected to a DC power supply. The modest commotion was provided by a magnetic stirrer. After each experimental run, sample was kept for few minutes and measured absorbance and COD values. The distance between electrodes was kept constant. Throughout the experiment, samples were ejected at specified time intervals and they were analyzed. All the runs were performed at constant temperature . After each specific run electrodes were washed with dil $\mathrm{H}_{2} \mathrm{SO}_{4}$ and IOP reactor with dil $\mathrm{HCl}$. The experimental setup of indirect electrochemical oxidation process is shown in (Figure 3).

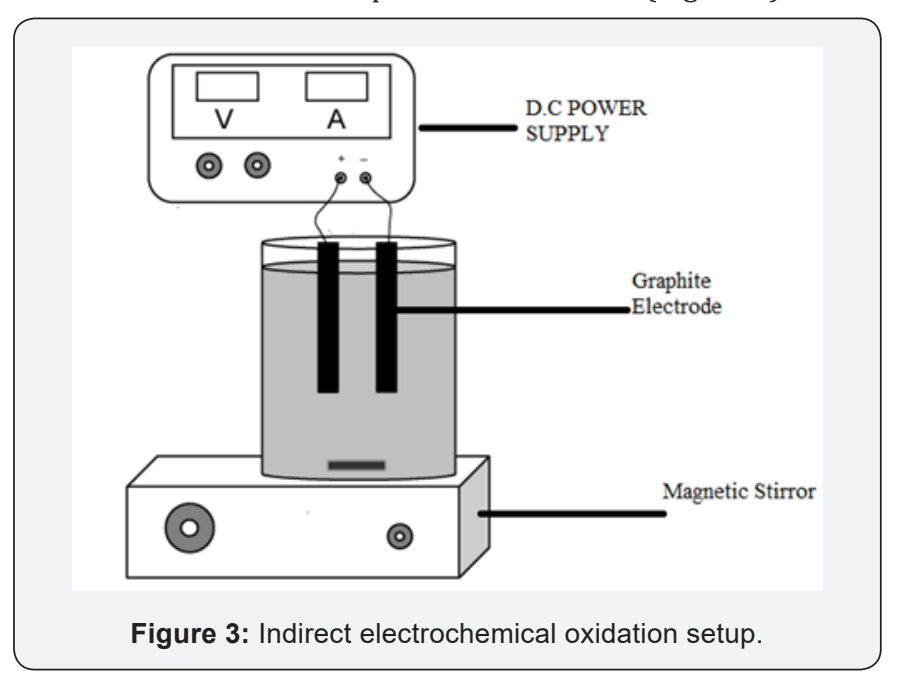

\section{Analytical method}

COD measurements were carried out according to the Standard Methods for Examination of Water and Wastewater [43]. The absorbance was measured by using Shimadzu Model
UV-160 double beam spectrophotometer. The $\mathrm{pH}$, conductance and TDS were measured with (Portable pH/EC/TDS/ Temperature HANNA, H19811-5). The $\mathrm{pH}$ and conductivity were adjusted by $\mathrm{NaOH}$ or $\mathrm{HCl}$, and $\mathrm{NaCl}$ (Merck), respectively.

\section{Calibration Curves}

The concentration of RR120 in a sample was determined by standard calibration curve method using concentrations (50mg/L - $300 \mathrm{mg} / \mathrm{L})$.

\section{Determination of removal efficiencies}

The removal efficiencies of dyes were calculated as:

$(\%)$ Color Removal efficiency $=\left(\mathrm{X}_{\mathrm{o}}-\mathrm{X}_{\mathrm{t}}\right) / \mathrm{Xo} \bullet 100$

Where $X_{o}$ - the [dye] initial and $X_{t}$-values [dye] final concentration in IOP system after a certain reaction time $(t)$. The COD removal values were deliberated by the following equation

$\%$ COD Removal $=([\mathrm{COD}]$ initial- $[\mathrm{COD}] \mathrm{t}) /[\mathrm{COD}]$ initial $\bullet 100$ -----------(12)

Where $[C O D]_{\text {initial }}$ represent the initial values of COD of dyes system. The [COD]t represent values of COD in IOP system after a certain reaction time $(\mathrm{t})$ period. Moreover the Chemical Oxygen Demand (COD) test is an indicator of organic component in waste water.

\section{Central composite design (CCD) for the removal of RR120}

The Indirect oxidation process (IOP) depends on different operational parameters. These parameters were successfully optimized by a statistical tool known as RSM based on CCD. By this approach combine and interactive effect of factors were evaluated. The optimization of parameters was designs for the determination of \% color and COD removal. Moreover the operation variables including [dye], $[\mathrm{NaCl}]$, initial $\mathrm{pH}$, reaction time were selected. A CCD model with four factors and five levels was designed to optimize the parameters for the color and COD removal. About thirty one (31) experimental runs were proceeded. The second-order polynomial model as represented in equation (13) was applied to assess the correlations between the responses and also the freelance of variables [44].

$$
Y=\beta_{o}+\sum_{i=1}^{4} \beta_{i} x_{i}+\sum_{i=1}^{4} \sum_{j=1}^{4} \beta_{i j} x_{i} x_{j}+\sum_{i=1}^{4} \beta_{i i} x_{i}^{2}(13)
$$

Where $Y$ is the predicted function; $\beta_{0}$ is an intercept; $\beta \mathrm{i}, \beta \mathrm{ii}$, and $\beta \mathrm{ij}$ are the linear coefficient, the quadratic coefficient, and the interaction coefficient, respectively. The $\mathrm{X}_{\mathrm{i}}$ and $\mathrm{X}_{\mathrm{i}}$ represent the coded independent factors (Table 1).

\section{Result and Discussion}

\section{Surface and Contour plots analysis}

Figures $4 \& 5$ show the surface plots obtained from the linear models built from the experimental results. Three dimensional (3D) plots are drawn to check the effect of each variable on 
responses. The surface plots of the quadratic model with two variables kept constant at their zero level and the other two varying within the experimental ranges were shown in (Figures 4 \& 5). Response surface plots provide a method to predict the decolorization efficiency for different values of the tested variables [45]. Plots are clearly showing the variation in target

Table 1: Experimental runs and corresponding responses. response due to variation in operational parameters levels. From the results, it is observed that all the combined process variables show the significant effect on the color removal and COD removal rate in indirect electroxidation process treatment process (Figure $4 \& 5$ ).

\begin{tabular}{|c|c|c|c|c|c|c|}
\hline Run & $A=[\operatorname{dye}](\mathrm{mg} / \mathrm{L})$ & $\mathrm{B}=\operatorname{NaCl}(\mathrm{g} / \mathrm{L})$ & $\mathrm{C}=\mathrm{pH}$ & $\mathrm{D}=\operatorname{Time}(\mathrm{min})$ & \% Color Removal & \%COD removal \\
\hline 1 & 250 & 1.25 & 9 & 15 & 18 & 87 \\
\hline 2 & 200 & 1 & 7 & 20 & 40 & 97 \\
\hline 3 & 150 & 1.75 & 9 & 15 & 86 & 98 \\
\hline 4 & 300 & 1.5 & 7 & 20 & 88 & 87 \\
\hline 5 & 150 & 1.75 & 9 & 25 & 100 & 92 \\
\hline 6 & 150 & 1.25 & 9 & 25 & 77 & 97 \\
\hline 7 & 200 & 1.5 & 11 & 20 & 67 & 93 \\
\hline 8 & 150 & 1.25 & 5 & 15 & 57 & 87 \\
\hline 9 & 200 & 1.5 & 3 & 20 & 93 & 87 \\
\hline 10 & 250 & 1.75 & 9 & 25 & 54 & 94 \\
\hline 11 & 200 & 1.5 & 7 & 20 & 80 & 98 \\
\hline 12 & 250 & 1.25 & 5 & 15 & 50 & 80 \\
\hline 13 & 250 & 1.25 & 9 & 25 & 54 & 98 \\
\hline 14 & 150 & 1.75 & 5 & 15 & 71 & 97 \\
\hline 15 & 200 & 1.5 & 7 & 30 & 93 & 87 \\
\hline 16 & 150 & 1.25 & 9 & 15 & 54 & 87 \\
\hline 17 & 200 & 1.5 & 7 & 10 & 51 & 80 \\
\hline 18 & 200 & 1.5 & 7 & 20 & 84 & 98 \\
\hline 19 & 200 & 1.5 & 7 & 20 & 83 & 87 \\
\hline 20 & 100 & 1.5 & 7 & 20 & 80 & 87 \\
\hline 21 & 200 & 1.5 & 7 & 20 & 80 & 80 \\
\hline 22 & 200 & 1.5 & 7 & 20 & 82 & 73 \\
\hline 23 & 250 & 1.75 & 9 & 15 & 18 & 98 \\
\hline 24 & 250 & 1.75 & 5 & 15 & 48 & 87 \\
\hline 25 & 200 & 1.5 & 7 & 20 & 81 & 97 \\
\hline 26 & 250 & 1.75 & 5 & 25 & 78 & 87 \\
\hline 27 & 150 & 1.75 & 5 & 25 & 83 & 98 \\
\hline 28 & 150 & 1.25 & 5 & 25 & 83 & 87 \\
\hline 29 & 200 & 2 & 7 & 20 & 90 & 87 \\
\hline 30 & 200 & 1.5 & 7 & 20 & 83 & 80 \\
\hline 31 & 250 & 1.25 & 5 & 25 & 64 & 93 \\
\hline
\end{tabular}




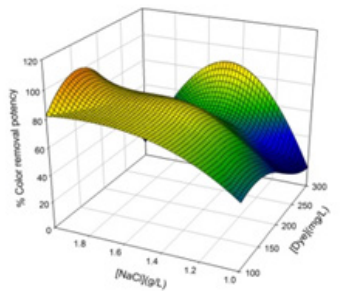

il

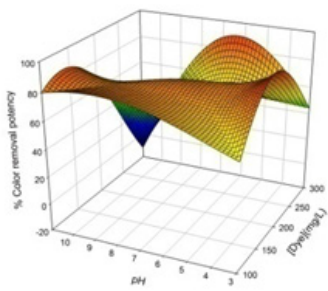

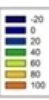

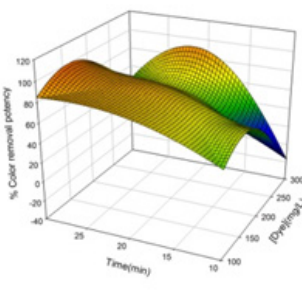

意

c
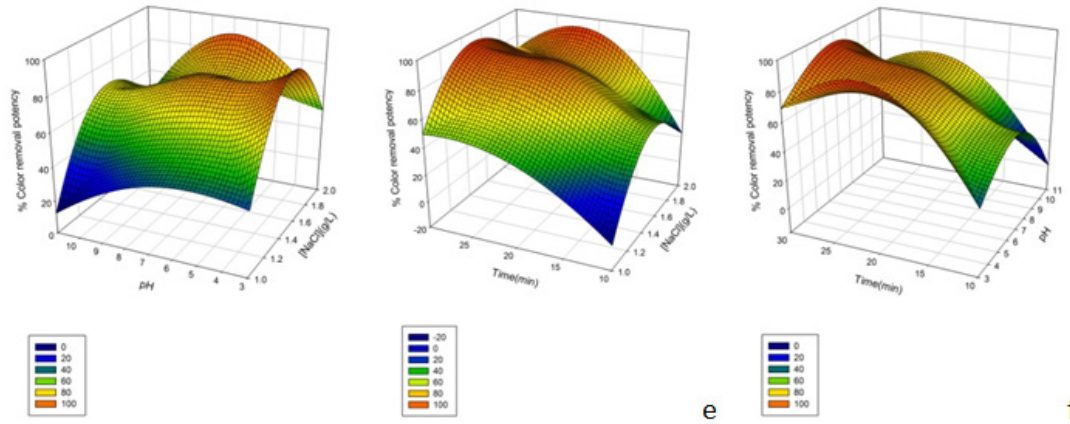

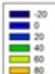

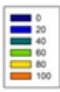

d

Figure 4: Response surface plots for the \% color removal of RR120.
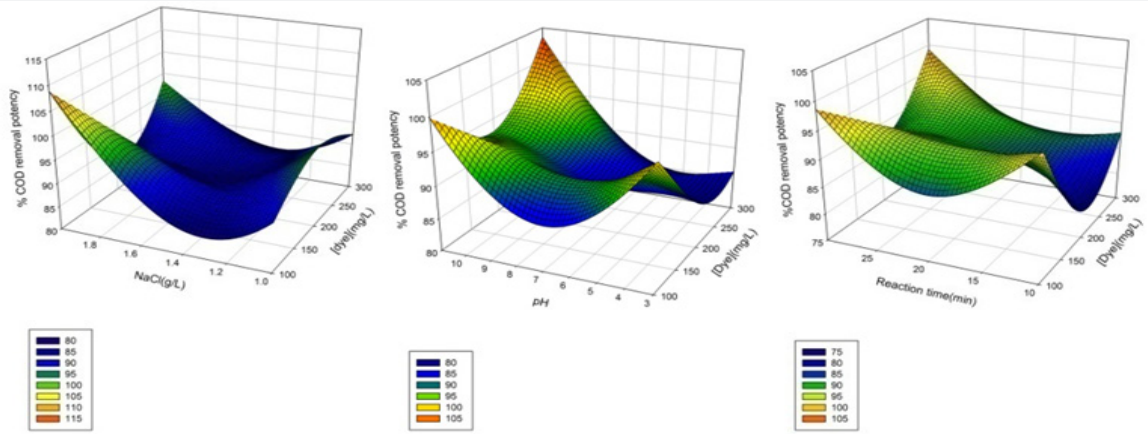

僬

a
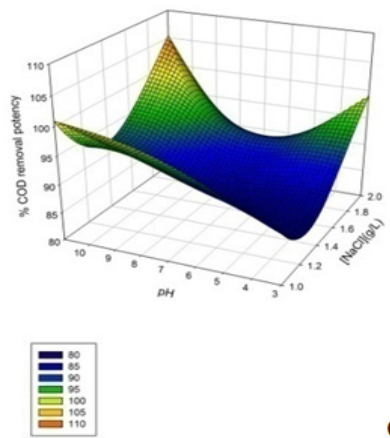

b

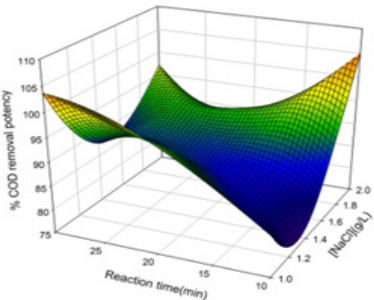

d 笶
C

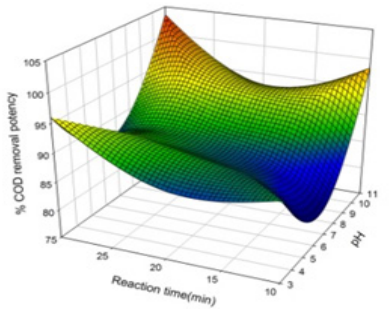

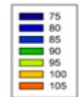

Figure 5: Response surface plots for the \% COD removal potency under the effect of $(\mathrm{a})[\mathrm{dye}](\mathrm{mg} / \mathrm{L})$ and $\mathrm{NaCl}(\mathrm{g} / \mathrm{L})(\mathrm{b}))[\mathrm{dye}](\mathrm{mg} / \mathrm{L})$ and pH (c) $[$ Dye $](\mathrm{mg} / \mathrm{L})$ and Reaction time $(\mathrm{min})(\mathrm{d}) \mathrm{NaCl}(\mathrm{g} / \mathrm{L})$ and $\mathrm{pH}(\mathrm{e}) \mathrm{NaCl}(\mathrm{g} / \mathrm{L})$ and Reaction time(min) (f) $\mathrm{pH}$ and Reaction time(min). 


\section{Effect of initial dye concentration}

The influence of the initial dye concentration on decolorization potency was studied at the dye concentrations (100-300 mg/L). The negligible changes were observed when dye concentration was changed from 100 to $200 \mathrm{mg} / \mathrm{L}$ at [ $\mathrm{NaCl}]$ $=1.5 \mathrm{~g} / \mathrm{L}, \mathrm{pH}=7$ and reaction time $=20 \mathrm{~min}$. (Figures $4 \mathrm{a}-4 \mathrm{c}$ ) show the variation in \% color removal potency due to changes in dye concentration with respect to other operational parameters.

\section{Effect of $\mathrm{NaCl}$ concentration}

In indirect oxidation process chlorine/hypochlorite were produced that causes degradation of dye molecule. In the present study, the $\mathrm{NaCl}$ concentration was varied from 1 to $2.0 \mathrm{~g} / \mathrm{L}$ at a constant potential of $15 \mathrm{~V}$. (Figure 13a-13e) show rapid decoloration due to faster breakdown of azo linkages and the intermediates are formed and oxidized into $\mathrm{CO}_{2}$ and $\mathrm{H}_{2} \mathrm{O}$ at a much lower rate [46]. It was observed that the rate of color removal is faster compeer to COD due to the fast degradation of azo linkages [47].

The $\%$ color removal potency was increased from $40 \%$ to $90 \%$ when amount of electrolyte was varied from 1 to $2 \mathrm{~g} / \mathrm{L}$ at [dye] $=200 \mathrm{mg} / \mathrm{L}, \mathrm{pH}=7$ and reaction time $=20 \mathrm{~min}$. The oxidizing agent form during electrolysis of aqueous $\mathrm{NaCl}$ solution are hypochlorite (hypochlorous acid), chlorate (chloric acid) and oxygen [48]. Among them, hypochlorous acid was assumed to be the main oxidizer in the dye effluent because of its high oxidation potential compared to the other oxidizer forms.

$$
\begin{aligned}
& \mathrm{Cl}_{2}+\mathrm{H}_{2} \mathrm{O}------>\mathrm{HCl}+\mathrm{HOCl}---1 \\
& \mathrm{RR} 120+4 \mathrm{HOCl}-------->2 \mathrm{CO}_{2}+2 \mathrm{H}_{2} \mathrm{O}+4 \mathrm{HCl}---
\end{aligned}
$$

Anodic hypochlorous acid generation:

$$
8 \mathrm{Cl}^{-}+4 \mathrm{HCl}--------->>4 \mathrm{HOCl}+4 \mathrm{HCl}+8 \mathrm{e}^{-}---------(16)
$$

Cathode:

$$
2 \mathrm{H}_{2} \mathrm{O}+8 \mathrm{e}^{-}--------->4 \mathrm{H}_{2}+80 \mathrm{H}^{-}
$$

The discrepancy in experiment observation suggested that another reaction is taking place in addition to the anodic oxidation and the direct oxidation by molecular oxygen. Moreover the conversion of inactive molecular oxygen to active oxygen is one known cathodic reaction. The electrochemical reduction of molecular oxygen has been studied for hydrogen peroxide production [21-23] and in situ generation of $\mathrm{H} 2 \mathrm{O} 2$ $[49,50]$ explain that our experimental results are similar to electro reduction of externally added oxygen to active oxygen occurs in place of the cathodic evolution of hydrogen gas.

Moreover the cathodic electro generation of active oxygen occurs reacts with dye molecules. The oxidation of organic compound by hypochlorous acid is represented as:

$\mathrm{RR} 120+4 \mathrm{HOCl}--------->2 \mathrm{CO}_{2}+2 \mathrm{H}_{2} \mathrm{O}+4 \mathrm{HCl}$

Oxidation reaction of organic compound by active oxygen such as hydrogen peroxide:
$\mathrm{RR} 120+4 \mathrm{H}_{2} \mathrm{O}_{2}--------->2 \mathrm{CO}_{2}+\mathrm{H}_{2} \mathrm{O}-\cdot-\cdot-----$

Anodic hypochlorous acid generation:

$8 \mathrm{Cl}^{-}+4 \mathrm{HCl}--------->4 \mathrm{HOCl}+4 \mathrm{HCl}+8 \mathrm{e}^{-----}$

Cathodic hydrogen peroxide evolution:

$\mathrm{H}_{2} \mathrm{O}+\mathrm{O}_{2(\mathrm{aq})}+8 \mathrm{e}^{-}--------->\mathrm{H}_{2} \mathrm{O}_{2}+\mathrm{OH}^{-}$

\section{Effect of initial pH}

Figure $4 \mathrm{~b}-4 \mathrm{f}$ show the influence of initial $\mathrm{pH}$ on electrochemical removal of RR120. The \% color removal potency was observed in the order of pHs at $3(93 \%)>\mathrm{pH} 7(80 \%)>\mathrm{pH} 11(67 \%)$. The optimum $\mathrm{p}^{\mathrm{H}}$ range for RR120 removal with graphite anode and cathode is neutral to slightly acidic, which may be due to existing active chlorine in the solution. Moreover hypochlorous acid or hypochlorite is the major oxidant produced in the presence of chloride. The dissociation constant of $\mathrm{HClO} / \mathrm{ClO}-(\mathrm{pKa})$ is 7.54 at $25^{\circ} \mathrm{C}$ [51]. Consequently at alkaline $\mathrm{PH}$ hypochlorite $(\mathrm{E} 0=$ $0.89 \mathrm{~V}$ vs. SHE) dominantly exist compeer to hypochlorous acid, whose oxidative ability is comparatively weaker [52]. Therefore, the indirect oxidation ability in alkaline range becomes lower than others. Additionally, the RR120 is an anionic dye and it loss positive counter ions in alkaline medium [53]. They have competing effects with the chloride ions for the adsorption sites on the anode surface and thereby affected the production of active chlorine to some extent [54].

\section{Effect of reaction time}

The reaction time is the significant factor. The $\%$ color removal potency was increased from $51 \%$ to $84 \%$ when the reaction time was varied from 10 to $20 \mathrm{~min}$ at [dye] $=200 \mathrm{mg} / \mathrm{L}$, $\mathrm{pH}=7$ and $[\mathrm{NaCl}]=1.5 \mathrm{~g} / \mathrm{L}$. At optimum values [dye] $=100 \mathrm{mg} / \mathrm{L}$, $[\mathrm{NaCl}]=2 \mathrm{~g} / \mathrm{L}, \mathrm{pH}=7$, reaction time $=25 \mathrm{~min}, 91 \%$ color removal potency was observed. The (Figures $4 \mathrm{c}-4 \mathrm{f}$ ) shows the effect of reaction time on \% color removal potency.

\section{Color removal efficacy}

The color removal was observed due to cleavage of azo linkages so the color abstraction rate is higher compared to \% COD removal. Moreover during the reaction the intermediates were engendered from dye degradation that show resistant to chlorine and hypochlorus acid attack and it resulted decrease in the \% COD abstraction rate [55]. The study of operational parameters on IOP process show that they all have a consequential effect on the process. The \% COD removal potency shows similar pattern at all combination of factors levels.

\section{Effect of dye concentration on \% COD removal potency}

It was cleared from the observation that when concentration of RR120 was changed from 100 to $200 \mathrm{mg} / \mathrm{L}$ the \% COD removal potency was observed similar at $\mathrm{NaCl} 1.5 \mathrm{~g} / \mathrm{L}, \mathrm{pH} 7$ and retention time $20 \mathrm{~min}$. As shown in (Figures 5a-5c). Moreover the present findings show that dye concentration is not affected by the variation of concentration. Moreover \% COD removal potency was significantly affected (Figure 5). 


\section{Effect of $\mathrm{NaCl}$ concentration on \% COD removal potency}

The effect of supported electrolyte concentration on COD removal is shown in (Figures $5 \mathrm{a}, 5 \mathrm{~d}, 5 \mathrm{e}$ ). The presence of $\mathrm{NaCl}$ promotes the removal of COD. It was clear that the removal efficiency of COD increases with the increase in electrolyte concentration. The concentration of electrolyte also affected by the conductivity and it was observed that conductivity was increased by the addition of sodium chloride. Moreover chloride ions significantly reduces the adverse effects of other anions, such as $\mathrm{HCO}_{3}^{-}$and $\mathrm{SO}_{4} 2^{-}$, that could form an insulating layer on the surface of the electrodes and increases the resistance of the electrochemical cell. The increase in the removal efficiency of COD can be attributed by change in the ionic strength due to increase in conductivity of aqueous medium [56].

\section{Effect of $\mathrm{pH}$ on \% COD removal potency}

The $\mathrm{pH}$ is known to affect the structural stability of dye molecules (in particular, the degradation. Moreover the influence of $\mathrm{pH}$ confirms the importance of electro generated active chlorine for the color removal and, indirectly, on the COD abatement. The mineralization process appeared to be almost $\mathrm{pH}$ insensitive since it was mainly dependent on the oxidizing action of the hydroxyl radical produced on the electrode surface. Furthermore it can be concluded that, at acidic $\mathrm{pH}$, achieve the highest color and COD removals. The (Figures 5b,5d,5f ) shows that at lower initial $\mathrm{pH}$ values, relatively high color and COD removal were obtained which is in agreement with the corresponding theory.

The results showed that the COD removals are increased with increasing $\mathrm{pH}$ up to 5 . It indicates that acidic condition is more favorable for the treatment of dye effluent. In acidic conditions, hypochlorous acid was the major compound in the solution. Therefore higher rate of decolorization and degradation in acidic condition may be due to higher oxidation potential of hypochlorous acid. Above $\mathrm{pH}$, the rate of reaction was lowest. This result can be attributed to undesirable side reactions such as oxidation of free chlorine to chlorate and per chlorate, reactions involving loss of hypochlorite.

\section{Reaction time on \%COD removal potency}

Reaction time is an important parameter for controlling the reaction rate in electrochemical treatment process. The linear effect of electrolysis time on COD removal efficiency was studied during electrochemical treatment process by varying the electrolysis time from 10 to $30 \mathrm{~min}$, and the results are shown in (Figures 5c,5e,5f). From the observation, it is found that the percentage of COD removal was increased with increasing of electrolysis time up to $30 \mathrm{~min}$ [48]. In view of reducing the power consumption and optimizing the electrochemical oxidation process, the effects of electrolysis duration on COD removal were studied by varying the duration from 10 to $30 \mathrm{~min}$. The color and COD removal efficiency depends directly on the concentration of oxidants produced by the electrodes which in turn depends upon time. Moreover when the reaction time increases, the increase in the concentration of active chlorine was occurred. Consequently, an increase in the reaction time in turn increases the color and COD removal efficiency. The decolorization and degradation of the dye are mainly due to the formation of oxidants such as chlorine, ozone, and/or free radicals. The rapid decolorization indicated that initially dyes are fully degraded, giving colorless organic or inorganic products, which can further be treated for complete mineralization. Among the dye molecule, the nitrogen atoms of azo and heterocyclic aromatic ring amines are easy to oxidize. As revealed by various researchers on the electrooxidation of azo dyes, the chromophore azo group is easily broken to generation $\mathrm{N}_{2}$ gas as represented in Equation (29):

$$
\mathrm{R}-\mathrm{N}=\mathrm{N}-\mathrm{R}^{1}+2 \cdot \mathrm{OH} \rightarrow \mathrm{N}_{2}(\mathrm{~g})+\mathrm{ROH}+\mathrm{R}^{1} \mathrm{OH}
$$

However, the complete decolorization of the dye does not show complete COD removal. The decrease of COD shows that further degradation of the initial colorless products occurred along with the decolorization during the electrochemical treatment. It could be concluded that the rate of COD removal is lower than that of color removal, indicating that the azo bond degradation is the first step of the electrochemical degradation mechanism with the comparison of COD removal.

\section{CCD model validation and residuals analysis}

The experimental and the predicted responses and their correlation are quantitatively evaluated by coefficient $\left(R^{2}\right)$. The obtained $\mathrm{R}^{2}$ values suggested the good agreement to the observed results since this indicated about $76.91 \%$ variation in $\%$ color removal was explained by the respective model. The goodness of the fitted model was measured by the Adjusted $\mathrm{R}^{2}$ $\left(\right.$ Adj- $\mathrm{R}^{2}$ ) value (Table 2).

Table 2: Model Summary for \% color and COD removals of RR 120 by Indirect electrochemical oxidation process.

\begin{tabular}{|c|c|c|}
\hline & \multicolumn{2}{|c|}{$\begin{array}{c}\text { Indirect electrochemical oxidation } \\
\text { process(IOP) }\end{array}$} \\
\hline $\begin{array}{c}\text { Statistical } \\
\text { parameters }\end{array}$ & $\begin{array}{c}\text { \% Color removal } \\
\text { potency }\end{array}$ & $\begin{array}{c}\text { \% coD removal } \\
\text { potency }\end{array}$ \\
\hline $\mathrm{S}_{\text {(square mean of error) }}$ & 13.71 & 7.536 \\
\hline $\mathrm{R}^{2}$ & $76.91 \%$ & $35.75 \%$ \\
\hline $\mathrm{R}^{2}$ (adj) & $56.71 \%$ & $0.00 \%$ \\
\hline $\mathrm{R}^{2}$ (pred) & $0.00 \%$ & $0.00 \%$ \\
\hline
\end{tabular}

Furthermore the normality of the residuals is studied by Normal probability plots. The observed residuals were plotted against the expected values, as given by a normal distribution in (Figures 6 \& 7). The residuals from the analysis should be normally distributed. In practice, if number of observation were large then moderate divergence from normality do not critically influences the results. Moreover the normal probability plot of the residuals follow a straight line to fitted the linear model. Trends observed in (Figures 6 \& 7) reveal reasonably wellbehaved residuals for \% color and COD removal. Based on these plots, the residuals appear to be randomly scattered about zero. The (Figures $6 \mathrm{~d} \& 7 \mathrm{~d}$ ) illustrate the residuals in the order of 
the corresponding observations. It shows that the residuals in the plot fluctuate in an arbitrary pattern around the center line
(Figures 6 \& 7).

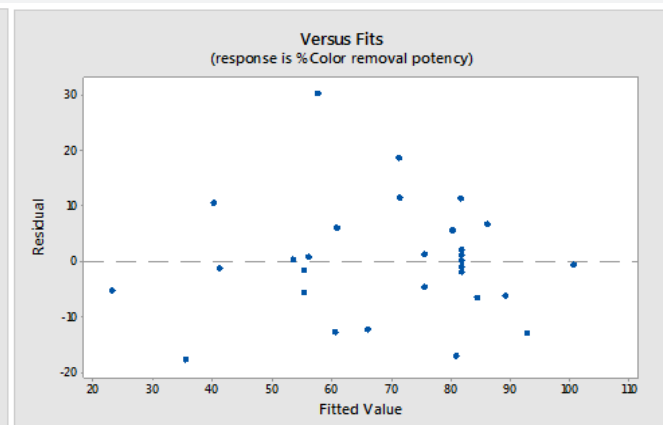

h

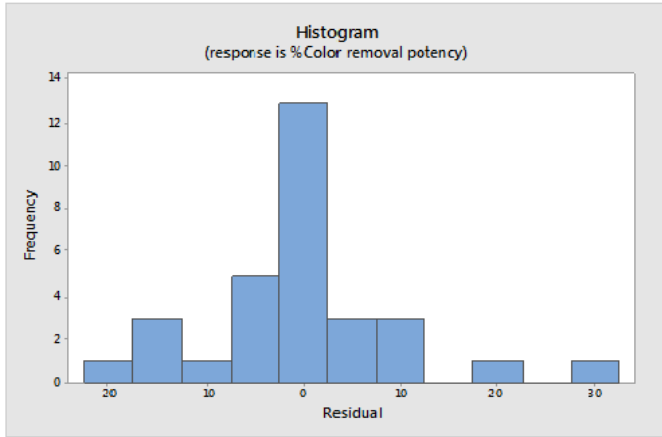

C

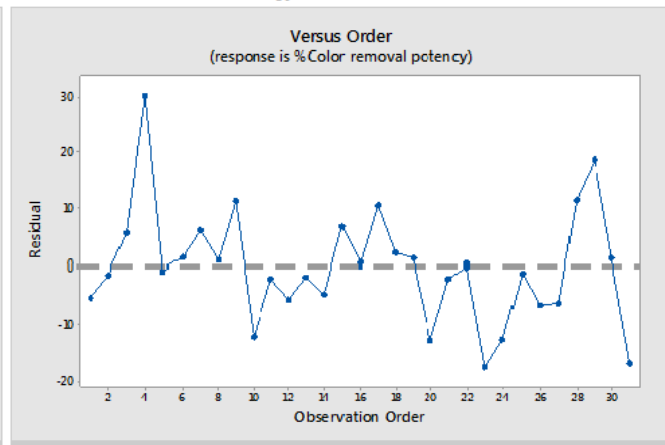

d

Figure 6: Residual plots for \% color removal potency of RR120 (a) Normal probability plot ( b) Residual versus fitted values (c) Histogram (d)Residual versus observation order.

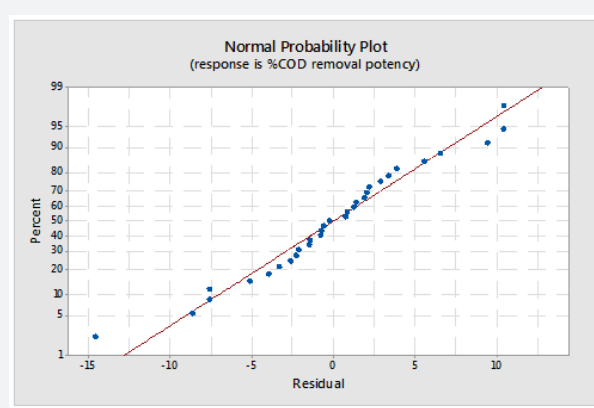

a

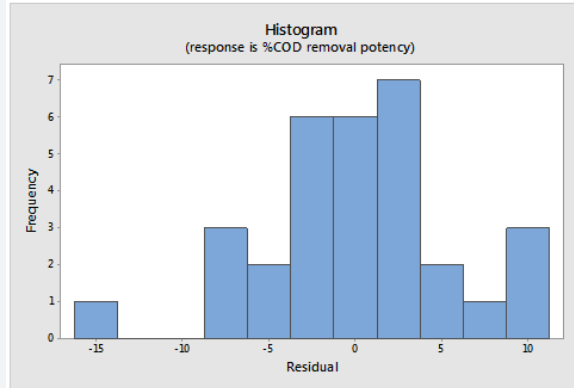

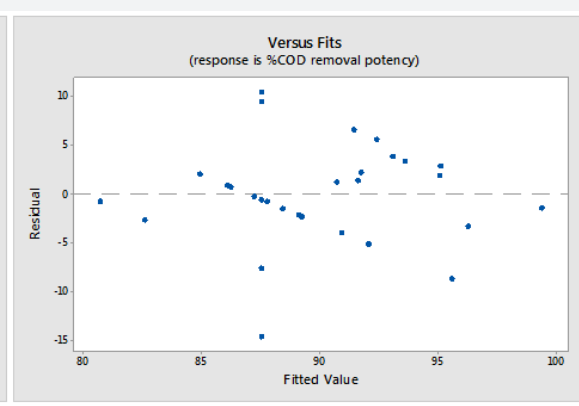

b

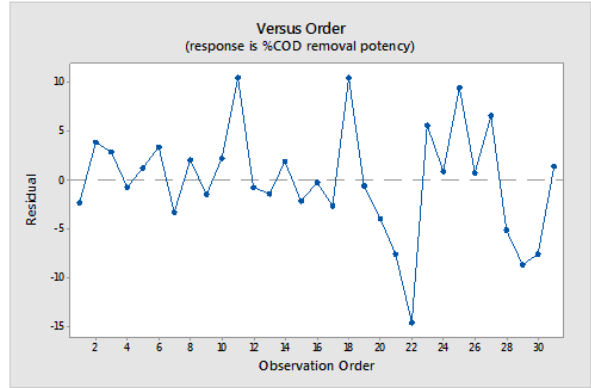

d

Figure 7: Residual plots for \% COD removal potency of RR120( a) Normal probability plot (b) Residual versus fitted values (c) Histogram (d)Residual versus observation order. 


\section{Pareto charts analysis}

It helps to identify the significant factors that influence the target response. The linear, quadratic and interactive significance of factors on response are identified. The amount of electrolyte, reaction time and dye concentration is the significant factors that influences on the \% color removal potency. The reaction time has a greater effect on responses compared to the other factors. This is due to the fact that reaction time provides more oxidizing agent interaction and enhances the \% color removal efficacy as shown in (Figures 8a,8b).

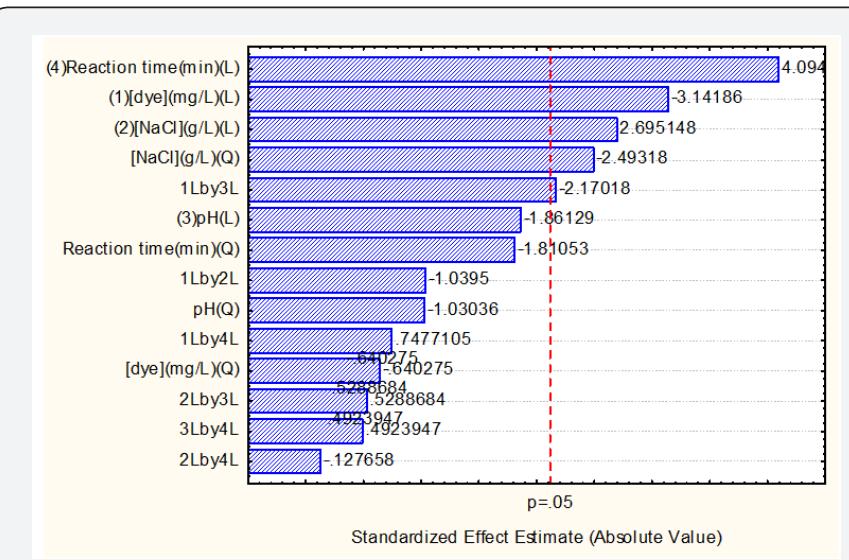

A

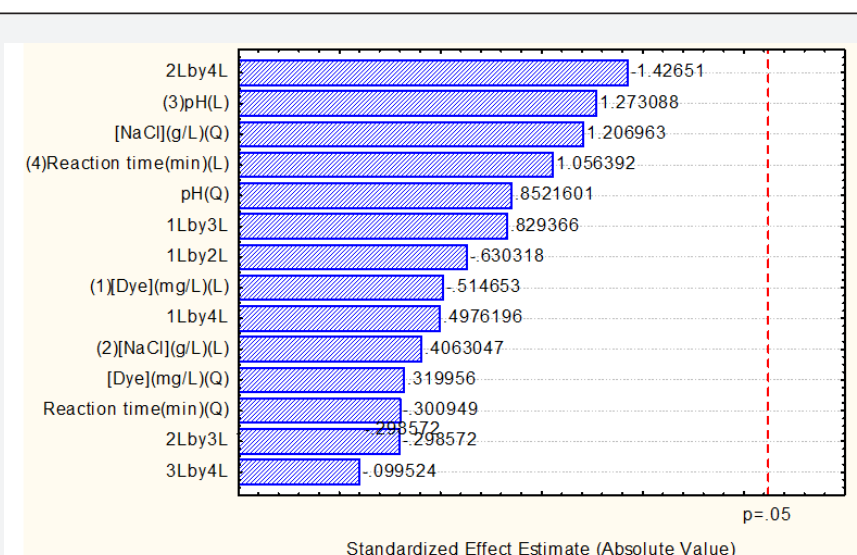

Standardized Effect Estimate (Absolute Value)

$\mathrm{B}$

Figure 8: The pareto chart for (a)\% Color removal potency(b) \% COD removal potency of RR120.

\section{Analysis of Variance}

ANOVA test is performed to study the influence of all factors on target response. Statistical significance of the model equation and model terms were evaluated by F-test and ANOVA [57]. Sum of squares (SS), DOF ( degree of freedom), mean of square (MS), and associated F-test of importance (F) can be calculated as :

$$
\mathrm{SS}_{\mathrm{A}}=\mathrm{KA} \Sigma_{\mathrm{i}=1}\left(\mathrm{~A}_{\mathrm{i}}^{2} / \mathrm{nA} \mathrm{A}_{\mathrm{i}}\right)-\mathrm{T}^{2} / \mathrm{N}
$$

While kA represent the number of the levels of factor $\mathrm{A}, \mathrm{nAi}$ is the number of observations at level $\mathrm{i}$. The factors $\mathrm{A}, \mathrm{Ai}$ are the sum of all observations of levels $\mathrm{i}$. The factors $\mathrm{A}$ and $\mathrm{T}$ are the sum of all observations. The SS of error is computed using as:

$$
\mathrm{SSe}=\mathrm{SS}_{\mathrm{T}}-\left(\mathrm{SS}_{\mathrm{A}}+\mathrm{SS}_{\mathrm{B}}+\ldots \ldots\right)-
$$

where SST is the total SS:

$$
\mathrm{SS}_{\mathrm{T}}={ }^{\mathrm{n}} \sum_{\mathrm{i}=1}\left(\mathrm{Yi}^{2}\right)-\mathrm{T}^{2} / \mathrm{N}-\cdot
$$

Where yi is the observation of i Moreover MS is calculated by dividing the sum of squares by the degrees of freedom. DOFA is estimated by $\mathrm{DOF}_{\mathrm{A}}=\mathrm{k}_{\mathrm{A}}-1$. The $\mathrm{F}$ value is calculated by $[45,58]$ :

$$
\mathrm{FA}=\mathrm{MS}_{\mathrm{A}} / \mathrm{MSe}
$$

While MSe represent the error of variance [58].

Table 3: Analysis of Variance for the removal of RR120 dye.

\begin{tabular}{|c|c|c|c|c|c|c|c|c|c|c|}
\hline Statistical parameters & \multicolumn{5}{|c|}{ \% Color removal potency } & \multicolumn{5}{c|}{ \% COD removal potency } \\
\hline Source & Model & Error & Lack-of-Fit & $\begin{array}{c}\text { Pure } \\
\text { Error }\end{array}$ & Total & Model & Error & Lack-of-Fit & $\begin{array}{c}\text { Pure } \\
\text { Error }\end{array}$ & Total \\
\hline DF & 14 & 16 & 10 & 6 & 30 & 14 & 16 & 10 & 6 & 30 \\
\hline Adj SS & 1002 & 3006 & 2992 & 14.9 & 1302 & 505.6 & 908.6 & 274.9 & 633.7 & 1414 \\
\hline Adj MS & 715.5 & 187.9 & 299.2 & 2.48 & $*$ & 36.11 & 56.78 & 27.49 & 105.6 & $*$ \\
\hline F-Value & 3.810 & $*$ & 120.8 & $*$ & $*$ & 0.64 & $*$ & 0.26 & $*$ & $*$ \\
\hline P-Value & 0.006 & $*$ & 0.000 & $*$ & $*$ & 0.800 & $*$ & 0.970 & $*$ & $*$ \\
\hline
\end{tabular}

The values of analysis of variance (ANOVA) are represented in (Table 3). Moreover the F-value was observed to be greater than the tabulated values of F-distribution the model. Moreover it is a good predictor of the experimental results, for a certain number of degrees of freedom at a level of significance $\alpha$. The $\mathrm{p}$-value $<0.05$ for RR120 so it confirming the adequacy of the fitted model. The [dye] (Linear), $\mathrm{NaCl}$ (Linear), reaction time(Linear), $(\mathrm{NaCl})^{2}$ (Quadratic), (Time) ${ }^{2}$ (Quadratic) and [Dye] $\times \mathrm{pH}$ ( 1 Linear by 3Linear) are significantly affecting the responses of RR120 removal .The model p-value > 0.05 for $\%$ COD removal potency indicating the insignificance of the model. The student $-\mathrm{t}$ distribution and the corresponding P-values, 
along with the parameter estimated are given in (Table 4). The P-values describe consequentiality of each of the coefficients, which in turn, are compulsory describe the pattern of the mutual

Table 4: Coded Coefficients for the removal RR120 dye. interactions between the variables studied. The more immensely colossal the magnitude of $\mathrm{t}$-value and minuter P-value, the more paramount is the corresponding coefficient [59].

\begin{tabular}{|c|c|c|c|c|c|c|c|c|c|c|c|c|}
\hline \multirow[b]{2}{*}{ Term } & \multicolumn{6}{|c|}{$\%$ Color removal potency } & \multicolumn{6}{|c|}{$\%$ COD removal potency } \\
\hline & Effect & Coef & SECoef & T-Value & P-Value & VIF & Effect & Coef & SECoef & T -Value & P-Value & VIF \\
\hline Constant & & 81.86 & 5.18 & 15.80 & 0.000 & & & 87.57 & 2.85 & 30.75 & 0.000 & \\
\hline [dye] & -17.58 & -8.79 & 2.80 & -3.14 & 0.006 & 1.00 & -1.58 & -0.79 & 1.54 & -0.51 & 0.614 & 1.00 \\
\hline $\mathrm{NaCl}$ & 15.08 & 7.54 & 2.80 & 2.70 & 0.016 & 1.00 & 1.25 & 0.62 & 1.54 & 0.41 & 0.690 & 1.00 \\
\hline pH & -10.42 & -5.21 & 2.80 & -1.86 & 0.081 & 1.00 & 3.92 & 1.96 & 1.54 & 1.27 & 0.221 & 1.00 \\
\hline Time & 22.92 & 11.46 & 2.80 & 4.09 & 0.001 & 1.00 & 3.25 & 1.63 & 1.54 & 1.06 & 0.306 & 1.00 \\
\hline [dye]×[dye] & -3.28 & -1.64 & 2.56 & -0.64 & 0.531 & 1.03 & 0.90 & 0.45 & 1.41 & 0.32 & 0.753 & 1.03 \\
\hline $\mathrm{NaCl} \times \mathrm{NaCl}$ & -12.78 & -6.39 & 2.56 & -2.49 & 0.024 & 1.03 & 3.40 & 1.70 & 1.41 & 1.21 & 0.245 & 1.03 \\
\hline $\mathrm{pH} \times \mathrm{pH}$ & -5.28 & -2.64 & 2.56 & -1.03 & 0.318 & 1.03 & 2.40 & 1.20 & 1.41 & 0.85 & 0.407 & 1.03 \\
\hline TimexTime & -9.28 & -4.64 & 2.56 & -1.81 & 0.089 & 1.03 & -0.85 & -0.42 & 1.41 & -0.30 & 0.767 & 1.03 \\
\hline$[$ dye] $\times \mathrm{NaCl}$ & -7.13 & -3.56 & 3.43 & -1.04 & 0.314 & 1.00 & -2.37 & -1.19 & 1.88 & -0.63 & 0.537 & 1.00 \\
\hline$[$ dye] $\times p H$ & -14.87 & -7.44 & 3.43 & -2.17 & 0.045 & 1.00 & 3.12 & 1.56 & 1.88 & 0.83 & 0.419 & 1.00 \\
\hline [dye]×Time & 5.12 & 2.56 & 3.43 & 0.75 & 0.465 & 1.00 & 1.87 & 0.94 & 1.88 & 0.50 & 0.626 & 1.00 \\
\hline $\mathrm{NaCl} \times p \mathrm{H}$ & 3.63 & 1.81 & 3.43 & 0.53 & 0.604 & 1.00 & -1.13 & -0.56 & 1.88 & -0.30 & 0.769 & 1.00 \\
\hline NaCl×Time & -0.88 & -0.44 & 3.43 & -0.13 & 0.900 & 1.00 & -5.37 & -2.69 & 1.88 & -1.43 & 0.173 & 1.00 \\
\hline pH $\times$ Time & 3.38 & 1.69 & 3.43 & 0.49 & 0.629 & 1.00 & -0.38 & -0.19 & 1.88 & -0.10 & 0.922 & 1.00 \\
\hline
\end{tabular}

\section{Regression Equations}

Based on second order polynomial model, an empirical relationship between the response and independent variables was attained and expressed by the following second-order polynomial equations:

\%Color removal potency $=-416+0.830 \mathrm{~A}+376 \mathrm{~B}+12.7 \mathrm{C}+$ 7.01 D-0.00066AA - 102.3 BB - 0.660 CC- 0.186 DD - 0.285 AB $-0.0744 \mathrm{AC}+0.0103 \mathrm{AD}+3.63 \mathrm{BC}-0.35 \mathrm{BD}+0.169 \mathrm{CD}$

\%COD removal potency $=79-0.130 \mathrm{~A}-9.3 \mathrm{~B}-4.29 \mathrm{C}+3.61$ $\mathrm{D}+0.000180 \mathrm{AA}+27.2 \mathrm{BB}+0.300 \mathrm{CC}-0.0170 \mathrm{DD}-0.095 \mathrm{AB}+$ $0.0156 \mathrm{AC}+0.00375 \mathrm{AD}-1.13 \mathrm{BC}-2.15 \mathrm{BD}-0.019 \mathrm{CD}--\cdot$

\section{Kinetic study}

In the indirect electrochemical oxidation process, the color or COD removal rate is proportional to the concentration of the dye compound and to the chlorine/hypochlorite concentration because the indirect oxidation is mediated by chlorine/ hypochlorite. Therefore, the kinetics for color or COD removal is estimated as: $-\mathrm{d}[$ Color $] / \mathrm{dt}=\mathrm{k}[$ Color $]\left[\mathrm{Cl}_{2}\right]$ or $-\mathrm{d}[\mathrm{COD}] / \mathrm{dt}=$ $\mathrm{k}[\mathrm{COD}]\left[\mathrm{Cl}_{2}\right](29)$.
The electrochemical oxidation involves the application of an electrical current to the dye wastewater containing chloride to convert into chlorine/hypochlorite. The chlorine/hypochlorite oxidizes the dye compound in the bulk solution and then get reduced to chloride ion. The process is then repeated in a catalytic fashion. Therefore, the concentration of chlorine/ hypochlorite during the electrolysis is assumed to be a constant, and so Equation (30) can be written as a pseudo-first-order kinetic equation:

$$
\left.-\mathrm{d}[\text { Color }] / \mathrm{dt}=\mathrm{K}^{1} \text { [Color }\right] \text { or }-\mathrm{d}[\mathrm{COD}] / \mathrm{dt}=\mathrm{K}^{1}[\mathrm{COD}]
$$

The log plots of the color or COD concentration show the plot of rate expression:

$$
\log \left([\text { Color }]_{\mathrm{t}} /\left[{ }_{\mathrm{Color}}\right]_{\mathrm{o}}\right)=-\mathrm{K}^{1} \mathrm{t} \text { or } \log \left([\mathrm{COD}]_{\mathrm{t}} /[\mathrm{COD}]_{\mathrm{o}}\right)=-\mathrm{K}^{1} \mathrm{t}
$$

The slope of the plot of $\log \left(C_{t} / C_{0}\right)$ versus time gives the value of rate constant $\mathrm{k}$ (reciprocal $\mathrm{min}$ ). The rate constant value obtained for the RR120 reactive dye is presented in (Table 5). It was reported that the organic pollutant abatement can be treated following pseudo-first order kinetics [60]. In particular, 
in our previous studies it was verified that the electrochemical dye degradation follows a pseudo-first order reaction [61]. The decolouration rate constants $(\mathrm{Kd})$ were calculated from the slope of semi logarithmic absorbance versus exposition time $(\mathrm{t})$, according to the kinetic Equation (33) [62].

$$
-\ln \left(A_{t} / A_{0}\right)=K_{D} \cdot t-\cdots-\cdot--
$$

The First order and second order kinetics model was utilized which represented as follows (Table 5):

$$
1 /([\mathrm{A}] \mathrm{t})=\mathrm{k} \cdot \mathrm{t}+1 /([\mathrm{A}] \mathrm{o})
$$

Table 5: Effect of initial dye concentration on electrochemical degradation of RR120 at different time intervals $(\mathrm{NaCl} 2 \mathrm{~g} / \mathrm{L}, \mathrm{pH} 5$ ,Reaction time $25 \mathrm{~min}$ ).

\begin{tabular}{|c|c|c|c|c|}
\hline \multirow{2}{*}{$\begin{array}{c}\text { Dye (mg/L) } \\
\text { RR 120 }\end{array}$} & \multicolumn{2}{|c|}{ First order } & \multicolumn{2}{c|}{ Second order } \\
\cline { 2 - 5 } & $\mathbf{k}_{1}$ (1/min) & $\mathbf{R}^{\mathbf{2}}$ & $\mathbf{k}^{\mathbf{2}}$ (g/mg min) & $\mathbf{R}^{\mathbf{2}}$ \\
\hline 50 & 0.191 & 0.989 & 0.619 & 0.0119 \\
\hline 100 & 0.0351 & 0.991 & 0.130 & 0.652 \\
\hline 150 & 0.0151 & 0.979 & 0.049 & 0.451 \\
\hline 200 & 0.0129 & 0.899 & 0.039 & 0.654 \\
\hline
\end{tabular}

\section{The UV-Vis scanning of RR120}

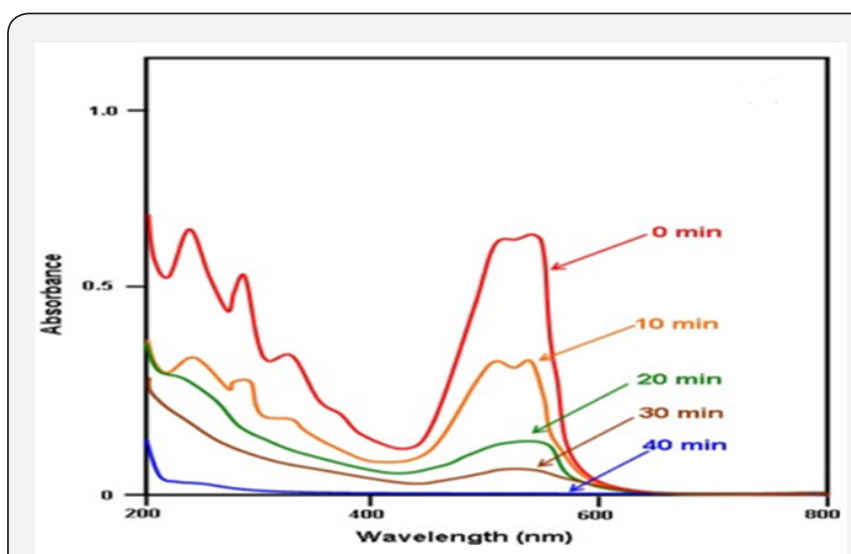

Figure 9: UV-visible spectra of RR120 during the indirect electrochemical oxidation process atdifferent time intervals (dye: $100 \mathrm{mg} / \mathrm{L}, \mathrm{NaCl}: 2 \mathrm{~g} / \mathrm{L}$ and Voltage $15 \mathrm{~V}$ time $40 \mathrm{~min}$ ).

The absorbance spectrum for RR120 shows the absorbance peaks at 392 and $273 \mathrm{~nm}$ that are belong to the azo chromophore and aromatic rings of dye molecule, respectively. It was observed that in the presence of hypochlorite, azo bond may break through two mechanisms. In both cases there will be amine compounds that can accept proton under weak acidic condition, and adsorbed on negative charged sites (cathode). On the other hand, oxidation of amid group presents in ortho-situation with respect to the azo bond tends to production of carboxylic derivatives that results weak acidic condition. The nitrogen in the azo bond can be directly reduced and through accepting hydrogen, the azo double bond transform to single bond and further to amine. The decrease of absorbance at $273 \mathrm{~nm}$ was indicative of the aromatic ring degradation [62,63]. As shown in (Figure 9).

\section{FTIR spectra analysis}

The chemical functionalities of material was categorized by transitory and transmitting the infrared (IR) beam. The (Figure 8) represent FTIR spectrum of RR120 dye. The characteristic peaks appeared near to $3500 \mathrm{~cm}-1$ represents the NitrogenHydrogen stretching was present outside the benzene ring. While the peak at $1365 \mathrm{~cm}^{-1}$ showing Carbon-Hydrogen (C$\mathrm{H}$ ) distortion in $\mathrm{CH}_{3}$ group. The peak at $1174 \mathrm{~cm}^{-1}$ is owing to Carbon -Hydrogen $(\mathrm{C}-\mathrm{H})$ stretching in benzene ring. The peak at $3000-3100 \mathrm{~cm}^{-1}$ represents stretching variation of $\mathrm{C}-\mathrm{H}$ in benzene. Moreover1400-1600 $\mathrm{cm}^{-1}$ represents $C=C$ in benzene ring. The low intensity absorption was observed from $4000 \mathrm{~cm}^{-1}$ to $2000 \mathrm{~cm}^{-1}$ as shown in (Figure 10).

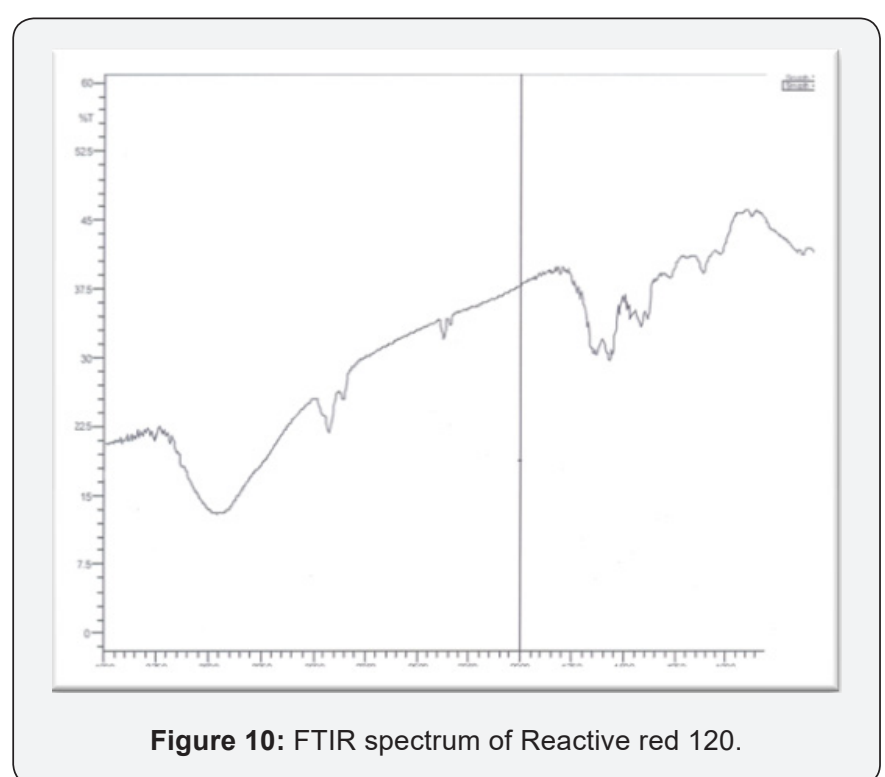

\section{Optimization of parameters}

The optimization of operational parameters focuses the increase in the response of color removal potency of dye. To solve this type of multi-objective optimization drawback, Derringer and Suich [64] recommended the desirability perform Equation (34) that is one in all the foremost appropriate ways. The overall desirability function, $\mathrm{D}$, is the mean value of the individual desirability functions:

$$
\mathrm{D}=\left(\prod_{-}(\mathrm{i}=1)^{\wedge} \mathrm{k} \text { di }\right)^{1 / \mathrm{k}}
$$

While $d_{i}$ denoting the individual desirability function for every response, and $\mathrm{k}$ the number of responses. The purpose of this function is to maximize the responses due to factors levels within the selected ranges [65]. Experimental tests were performed to verify the predicted values of responses at optimum values. The algorithm of multi-objective optimization Minitab software was used to obtain the prognosticated optimal values. Three attestation runs were performed to check the 
experimentally the optimal point. The optimal presaged values were in good accordance with the experimental ones. Based on these results, a central composite design was developed to optimize the IOP process. This process involves three major steps: performing the statistically designed experiments, estimating of coefficients in the proposed model and predicting the response of process and checking the validity of the model.

The optimum values of the process variables for the maximum decolorization efficiency and \% COD removal potency are shown in (Table 6). After verifying the experimental test with the presaged values, the results denoted that the maximal decolorization efficiency and \% COD abstraction potency were obtained when the values of each parameter were set as the optimum values, which was in good accordance with the value prognosticated from the model. It implicatively insinuates that the strategy used to optimize the decolorization conditions and \% COD abstraction potency and to obtain the maximal for the oxidation of RR120 is prosperous. The values obtained from authentic experiments, demonstrated the validation of the optimized conditions [66]. The result obtained for \% color removal and \% COD removal are depicted in the following (Table 6).

Table 6: Responses at optimum values.

\begin{tabular}{|c|c|c|c|c|}
\hline $\begin{array}{c}\text { Operational } \\
\text { parameters }\end{array}$ & \multicolumn{2}{|c|}{ Optimum values } & \multicolumn{2}{c|}{ Simulated dye effluent } \\
\hline & $\begin{array}{c}\text { \%Color } \\
\text { removal of } \\
\text { RR120 }\end{array}$ & $\begin{array}{c}\text { \% COD } \\
\text { removal }\end{array}$ & $\begin{array}{c}\text { \%Color } \\
\text { removal of } \\
\text { RR120 }\end{array}$ & $\begin{array}{c}\text { \% COD } \\
\text { removal }\end{array}$ \\
\hline [Dye]mg/L & 100 & 300 & $91 \%$ & $87 \%$ \\
\hline NaCl(g/L) & 2 & 1 & & \\
\hline pH & 5 & 5 & & \\
\hline Time(min) & 25 & 30 & & \\
\hline
\end{tabular}

\section{Main interaction plots}

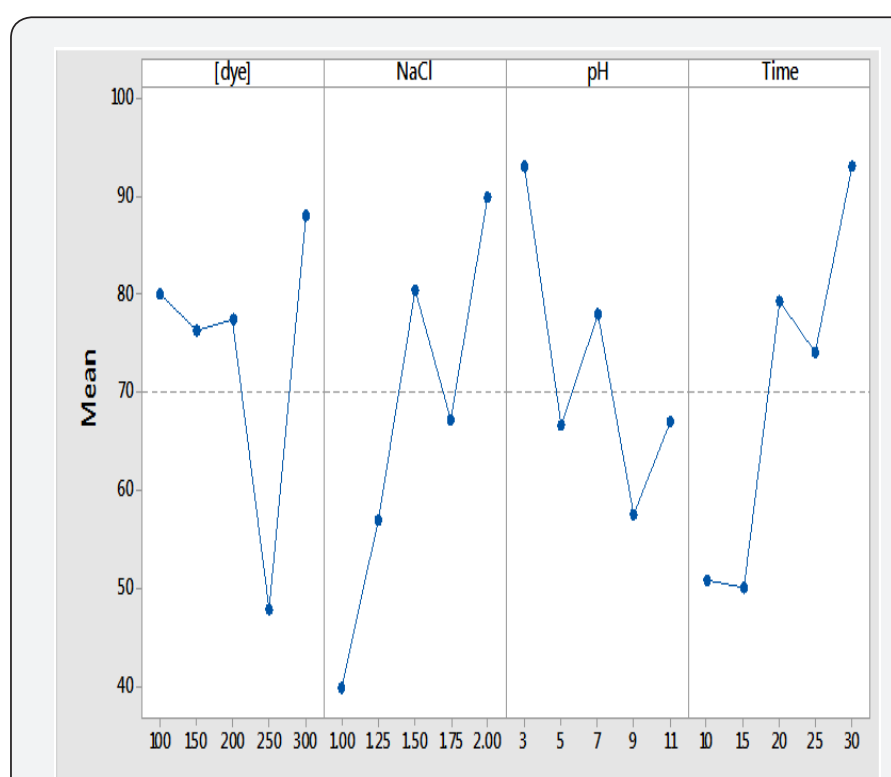

(a)

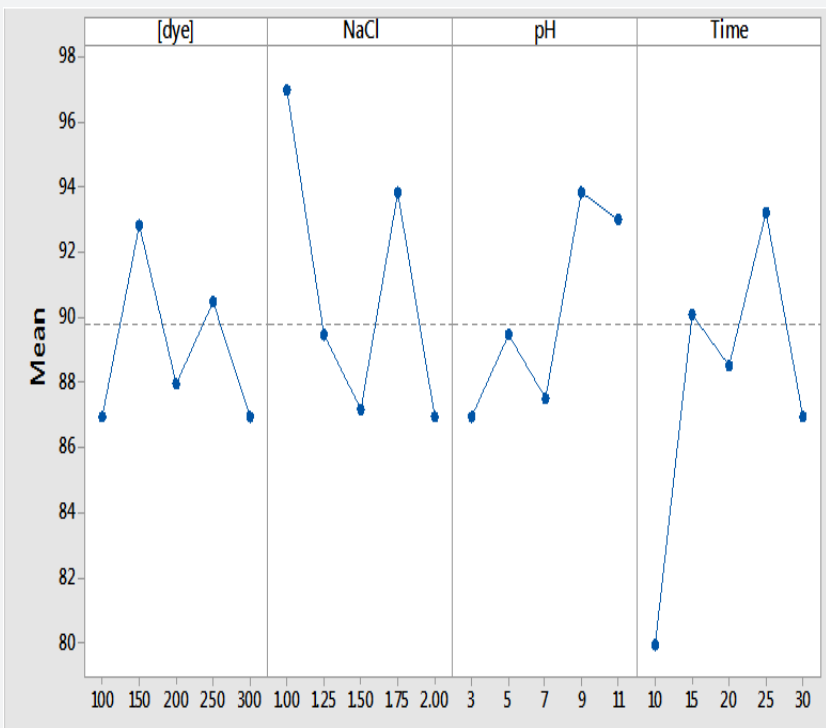

(b)

Figure 11: Main interaction plots for (a) \% color removal potency (b)\% COD removal potency.

Observation of main interaction plots clearly showing that operational parameters are not linear to experimental mean line. Its mean factors are significantly affecting the responses (Color and COD removal potency). Interactions plots are very helpful to identify the variation in responses due to change of factors levels. The analysis of the interactions between the experimental factors studied is shown in (Figures 11a,11b). The interaction between different factors is conspicuous for the both color and COD removal potency (Figure 11).

\section{Full interaction plots}

The full interaction plots are helpful to study the mutual interaction effect of factors at a time on response.
These plots show responses for the levels of one factor on the $\mathrm{x}$-axis and a separate line indicating the level of another factor. Moreover the parallel lines representing that no variation in target response occurs due to amendment in factors levels. If response slope is higher means additional robust interaction is present among levels of factors for the target response. These plots are reciprocal to ANOVA test. Interaction plots are very useful if there is a significant interaction among the factors for the response value. The lines are not fully parallel for \% color removal and \% COD removal potency as shown (Figures $12 \mathrm{a}, 12 \mathrm{~b})$. It means the response is significantly effecting from mutual interaction of factors levels (Figure 12). 


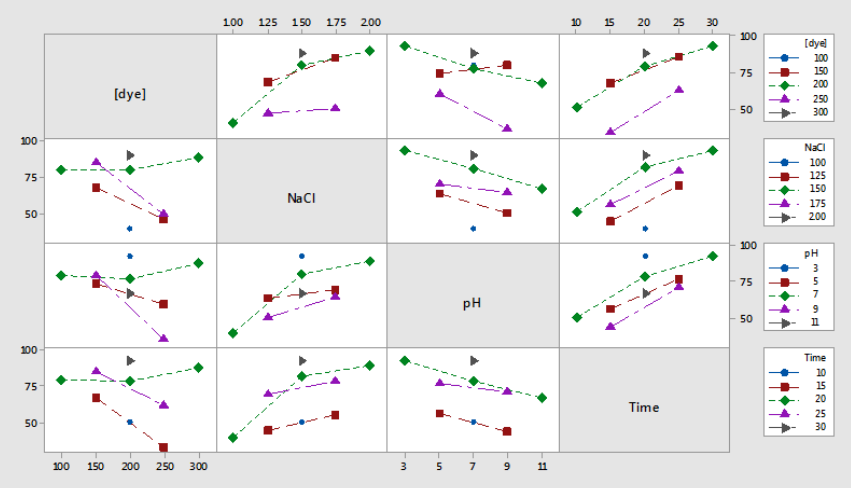

A

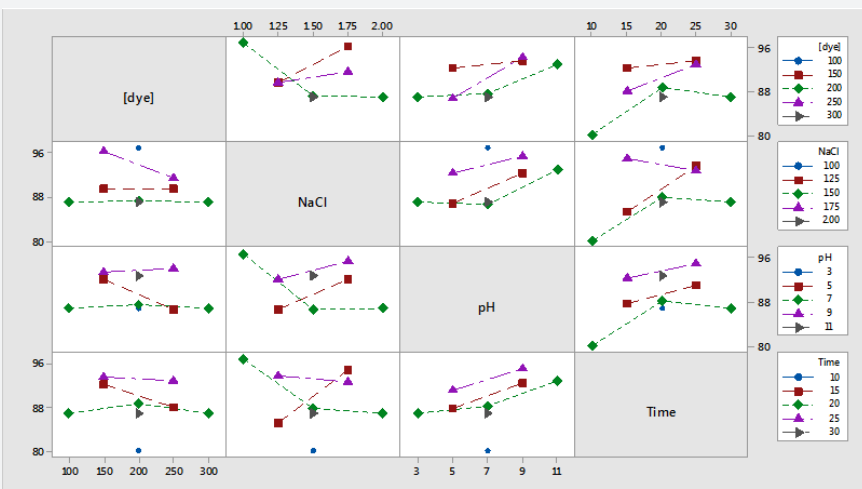

B

Figure 12: Full interaction plots for (a) \% color removal potency (b) \% COD removal potency.

\section{Scatter plots}
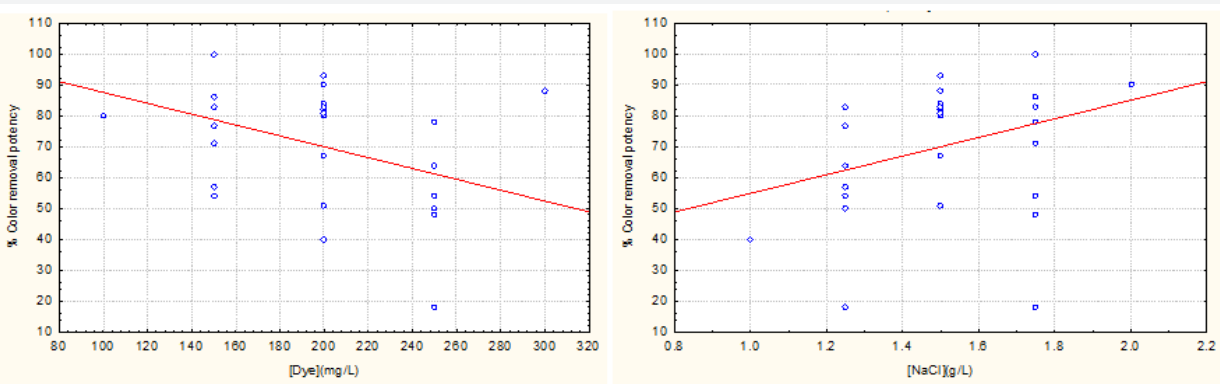

b
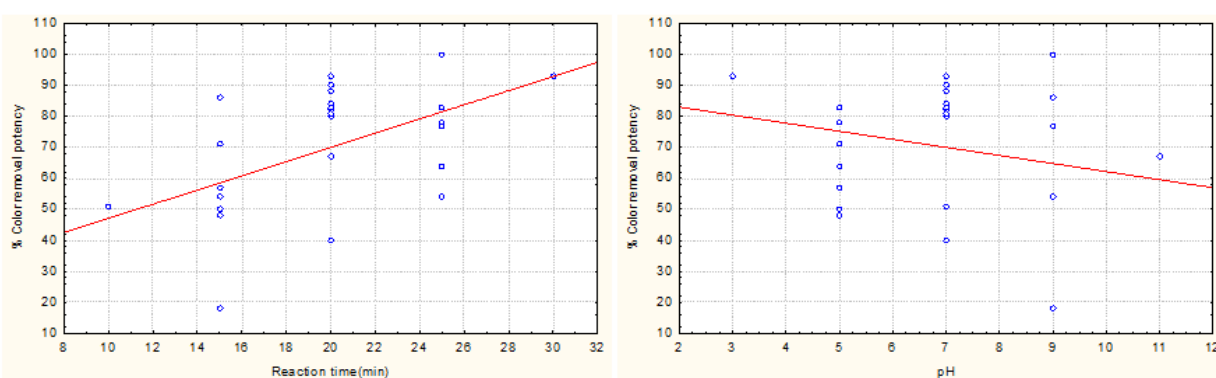

C

d

Figure 13: The scatter plots for \% color removal potency. 

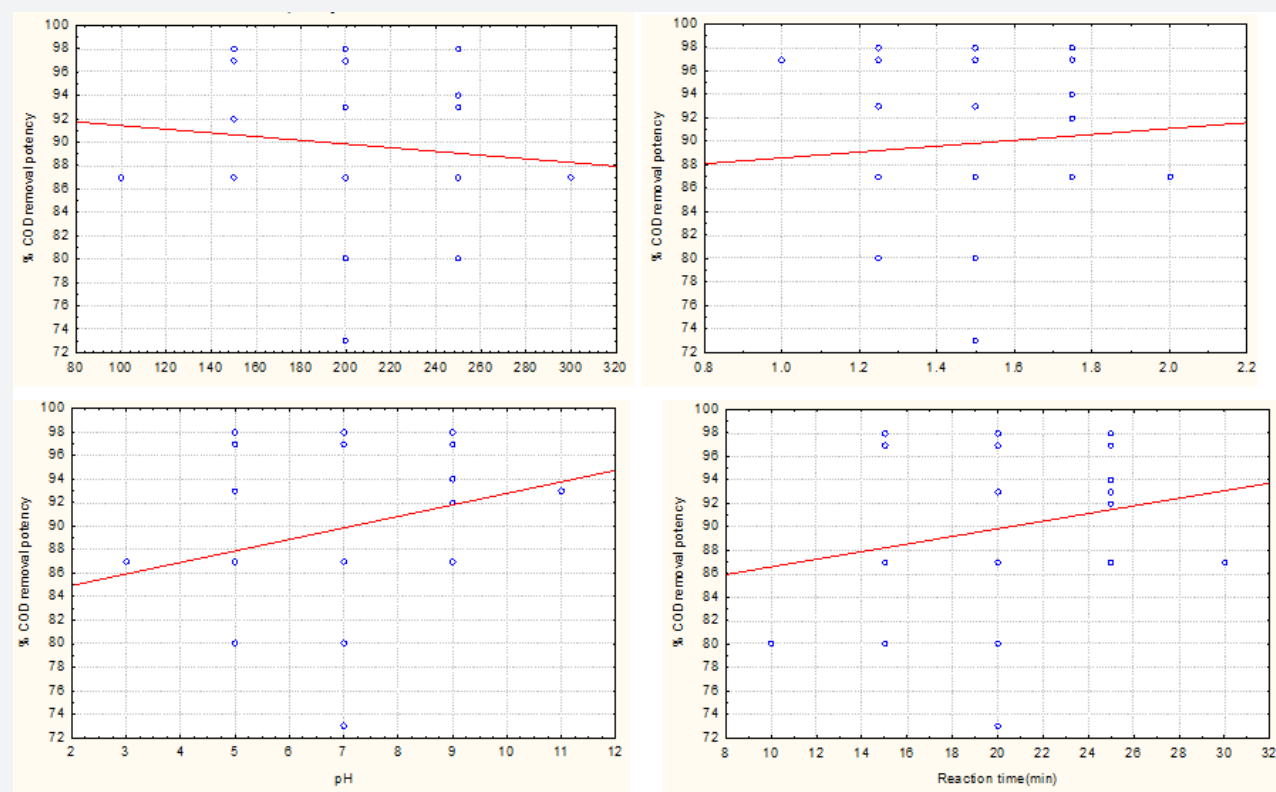

d

Figure 14: The scatter plots for \% COD removal potency.

The Scatter plots are exemplified in (Figures $13 \& 14$ ). It represent the correlation between RR120 dye removal,\% COD removal and the four variables.It is cleared from the plots that $\%$ color removal is decreases with increasing dye concentration and $\mathrm{pH}$. While it is increased when amount of electrolyte and reaction time are enhanced. The \% COD removal is increases with increase in $\mathrm{pH}$, amount of electrolyte and reaction time and dye concentration has a negative effect (Figures 13 \& 14).

\section{Electrical yield (current efficiency)}

The current efficiency is defined as the ratio between the electrical charge that actually used to oxidize the organic compounds and the total consumed electrical charge [67]. At a given time of electrolysis $t$, the average current efficiency (ACE) can be calculated as [68]: \%ACE $=\left[(\mathrm{COD})_{0}-(\mathrm{COD})_{\mathrm{t}}\right] \times \mathrm{FV} / 8 \mathrm{It}(35)$ (Table 7).

Table 7: The current efficiency and cost analysis at optimum values.

\begin{tabular}{|c|c|}
\hline Optimum parameters & Values \\
\hline$[$ Dye] $\mathrm{mg} / \mathrm{L}$ & 300 \\
\hline $\mathrm{NaCl} \mathrm{g/L}$ & 1 \\
\hline $\mathrm{pH}$ & 5 \\
\hline Reaction time(min) & 30 \\
\hline \% Current efficiency & 120 \\
\hline Cost Analysis & $0.3 \mathrm{US} \$ / \mathrm{dm}^{3}$ \\
\hline
\end{tabular}

Where $\operatorname{COD}_{0}$ and $\mathrm{COD}_{\mathrm{t}}$ are the chemical oxygen demand at initial time and the given time $\mathrm{t}\left(\mathrm{g} \mathrm{O}_{2} / \mathrm{L}\right)$, respectively, $\mathrm{U}$ is the voltage applied, I the current (A), t the treatment time (hr) and $\mathrm{V}$ is the volume of solution (L).

\section{Conclusion}

In this study, abstraction of RR120 utilizing indirect electrochemical oxidation method was performed prosperously. Comparing the rates of dye abstractions under different conditions the influences of the dye concentration, reaction time, $\mathrm{pH}$ of the solution were more paramount and pronounced. The results of UV-Vis spectrophotometer showed that at the terminus of treatment, aromatic compounds were abstracted from wastewater. The electrochemical treatment of simulated wastewater containing the investigated dye has been investigated in $\mathrm{NaCl}$ conductive electrolyte and under several operating conditions utilizing of graphite electrode. Both of the color and COD abstraction are incremented with increase in treatment time and amount of electrolyte. With the avail of hydroxyl radical and other radicals, the intermediates perpetuated to be degraded to carbon dioxide and water, which led to the mineralization of the dye solution. This result implicates that the optimization utilizing RSM predicated on the CCD can preserve the time and effort for a maximum abstraction of dye in wastewater.

\section{Acknowledgment}

The authors acknowledge the financial assistance supported by University of Karachi-Pakistan.

\section{References}

1. Mahmoodi NM, Arami M, Gharanjig K, Nourmohammadian F, Bidokhti AY (2008) Purification of water containing agricultural organophosphorus pollutant using titania nanophotocatalysis: 
Laboratory studies and numerical modeling. Desalination 230(1-3): 183-192.

2. Lacasse K, Baumann W (2004) Textile Chemicals: Environmental data and facts. Springer Science \& Business Media, Berlin, Germany, pp. 1180.

3. Rosi OL, Casarci M, Mattioli D, De Florio L ( 2007) Best available technique for water reuse in textile SMEs (BATTLE LIFE Project). Desalination 206(1-3): 614-619.

4. Aslam MM, Baig MA, Hassan I, Qazi IA, Malik M, et al. ( 2004) Textile wastewater characterization and reduction of its COD and BOD by oxidation. EJEAF Che 3(6): 804-811.

5. Bisschops I, Spanjers H (2003) Literature review on textile wastewater characterisation. Environmental technology 24(11): 1399-1411.

6. World Bank (2007) Environmental, Health, and Safety Guidelines for Textile Manufacturing, International Finance Corporation, World Bank Group, Washington DC, USA.

7. Correia VM, Stephenson T, Judd SJ (1994) Characterisation of textile wastewaters-a review. Environmental technology 15(10): 917-929.

8. Mahmoodi NM, Arami M (2006) Bulk phase degradation of Acid Red 14 by nanophotocatalysis using immobilized titanium (IV) oxide nanoparticles. Journal of Photochemistry and Photobiology A: Chemistry 182(1): 60-66.

9. Perey SJ, Brian L, Pei C, Chin Pao H, Danie CK (2006) Enhanced biodegradation of azo dyes using an integrated elemental ironactivated sludge system. II. Effects of physical-chemical parameters. Water Environ Res 78: 26-35.

10. Chatzisymeon E, Xekoukoulotakis NP, Coz A, Kalogerakis N, Mantzavinos D (2006) Electrochemical treatment of textile dyes and dye house effluents. Journal of Hazardous Materials 137(2): 998-1007.

11. Hao OJ, Kim H, Chiang PC (2000) Decolorization of wastewater. Critical reviews in environmental science and technology 30(4): 449-505.

12. Fernandes A, Morao A, Magrinho M, Lopes A Goncalves I (2004) Electrochemical degradation of $\mathrm{CI}$ acid orange 7. Dyes and Pigments 61(3): 287-296.

13. Sakalis, A, Mpoulmpasakos K, Nickel U, Fytianos K, Voulgaropoulos A (2005) Evaluation of a novel electrochemical pilot plant process for azodyes removal from textile wastewater. Chemical Engineering Journal 111(1): 63-70.

14. Susag RH (1968) BOD reduction by chlorination. Water Pollution Control Federation 40(11): R434-R444.

15. White GC (1999) Chemistry of chlorination. Handbook of chlorination and alternative disinfectants, $\left(4^{\text {th }}\right.$ edn), John Wiley and Sons, New York, USA, pp. 212-287.

16. Ramalho RS (1977) Introduction to wastewater Treatment. Academy Press, New York, USA.

17. Mulligan T, RDF (1980) Industrial wastewater and solid waste engineering, Ch Treatment of Industrial Wastewaters, New York, USA, pp. 173-190.

18. Comninellis C (1992) Electrochemical treatment of waste water containing phenols. In Institution of Chemical Engineers Symposium Series 127(92): 189-201.

19. Savall A (1995) Electrochemical treatment of industrial organic effluents. CHIMIA International Journal for Chemistry 49(1-2): 23-27.

20. Cooper P (1993) Removing colour from dyehouse waste waters - a critical review of techniques available. J Soc Dyers Colourists 109(3): 97-100.

21. Sudoh M, Kitaguchi H, Koide K (1985) Electrochemical production of hydrogen peroxide by reduction of oxygen. Journal of chemical engineering of Japan 18(5): 409-414.

22. Foller PC, Bombard R (1995) Processes for the production of mixtures of caustic soda and hydrogen peroxide via the reduction of oxygen. Journal of Applied Electrochemistry 25(7): 613-627.

23. Yamada N, Yaguchi T, Otsuka H, Sudoh M ( 1999) Development of Trickle-Bed Electrolyzer for On-Site Electrochemical Production of Hydrogen Peroxide. Journal of the electrochemical Society 146(7): 2587-2591.

24. Kuo WG (1992) Decolorizing dye wastewater with Fenton's reagent. Wat Res 26(7): 881-886.

25. Comninellis C (1994) Electrocatalysis in the electrochemical conversion/combustion of organic pollutants for waste water treatment. Electrochimica Acta 39(11-12): 1857-1862.

26. Rajkumar D, Palanivelu K (2004) Electrochemical treatment of industrial wastewater. J hazard mater 113(1): 123-129.

27. Chen G (2004) Electrochemical technologies in wastewater treatment. Separation and purification Technology 38(1): 11-41.

28. Martinez Huitle CA, Brillas E ( 2009) Decontamination of wastewaters containing synthetic organic dyes by electrochemical methods: a general review. Applied Catalysis B: Environmental 87(3):105-145.

29. Rajkumar D, Palanivelu K (2004) Electrochemical treatment of industrial wastewater. Journal of hazardous materials 113(1): 123129.

30. Fierro S, Ouattara L, Calderon EH, Passas Lagos E, Baltruschat $\mathrm{H}$, et al. ( 2009) Investigation of formic acid oxidation on $\mathrm{Ti} / \mathrm{IrO}_{2}$ electrodes. Electrochimica Acta 54(7): 2053-2061.

31. Panizza M, Barbucci A, Ricotti R, Cerisola G (2007) Electrochemical degradation of methylene blue. Separation and purification technology 54(3): 382-387.

32. Daneshvar N, Aber S, Vatanpour V, Rasoulifard MH (2008) ElectroFenton treatment of dye solution containing Orange II: Influence of operational parameters. Journal of Electro analytical Chemistry 615(2): 165-174.

33. Szpyrkowicz L, Radaelli M (2007) Electrochemical Single-Cell Reactor for Treatment of Industrial Wastewater Composed of a Spent Textile Bath. Separation Science and Technology 42(7): 1493-1504.

34. Myers RH, Montgomery DC (2002) Response surface methodology: process and product optimization using designed experiments, $\left(2^{\text {nd }}\right.$ edn), Wiley, USA.

35. Aktas N, Boyacı İH, Mutlu M, Tanyolac A (2006) Optimization of lactose utilization in deproteinated whey by Kluyveromyces marxianus using response surface methodology (RSM). Bioresource Technology 97(18): 2252-2259.

36. Yahia Cherif L, Yahiaoui I, Aissani Benissad F, Madi K, Benmehdi N, et al. (2014) Heat attachment method for the immobilization of $\mathrm{TiO}_{2}$ on glass plates: application to photodegradation of basic yellow dye and optimization of operation parameters, using response surface methodology. Ind Eng Chem Res 53(10): 3813-3819.

37. Cruz Gonzalez K, Torres Lopez O, Garcia Leon AM, Brillas E, Hernandez Ramirez A, et al. (2012) Optimization of electro-Fenton/BDD process for decolorization of a model azo dye wastewater by means of response surface methodology. Desalination 286: 63-68.

38. Almeida LC, Garcia Segura S, Bocchi N, Brillas E ( 2011) Solar photoelectro-Fenton degradation of paracetamol using a flow plant with a Pt/air-diffusion cell coupled with a compound parabolic collector: process optimization by response surface methodology. Applied Catalysis B: Environmental 103(1): 21-30.

39. Garcia Segura S, Almeida LC , Bocchi N, Brillas E (2011) Solar photoelectro-Fenton degradation of the herbicide 4-chloro- 
2-methylphenoxyacetic acid optimized by response surface methodology. Journal of hazardous materials 194: 109-118.

40. Zhang H, Ran X, Wu X, Zhang D (2011) Evaluation of electro-oxidation of biologically treated landfill leachate using response surface methodology. Journal of hazardous materials 188(1): 261-268.

41. El Ghenymy A, Garcia Segura S, Rodriguezn RM, Brillas E, El Begrani MS, et al. (2012) Optimization of the electro-Fenton and solar photoelectro-Fenton treatments of sulfanilic acid solutions using a pre-pilot flow plant by response surface methodology. Journal of hazardous materials 221: 288-297.

42. Ulucan K, Kabuk HA, Ilhan F, Kurt U (2014) Electrocoagulation process application in bilge water treatment using response surface methodology. Int J Electrochem Sci 9: 2316-2326.

43. APHA (1992) Standard methods for examination of water and wastewater. American Water Work Association, New York, USA.

44. Yu P, Chao X (2013) Statistics-based optimization of the extraction process of kelp polysaccharide and its activities. Carbohydr polym 91(1): 356-362.

45. Ravikumar K, Pakshirajan K, Swaminathan T, Balu K (2005) Optimization of batch process parameters using response surface methodology for dye removal by a novel adsorbent. Chemical Engineering Journal 105(3): 131-138.

46. Naumczyk J, Szpyrkowicz L, Zilio-Grandi F (2006) Electrochemical treatment of textile wastewater. Water Sci Technol 34: 17-24.

47. Sakalis A, Mpoulmpasakos K, Nickel U, Fytianos K, Voulgaropoulos A ( 2005) Evaluation of a novel electrochemical pilot plant process for azodyes removal from textile wastewater. Chemical Engineering Journal 111(1): 63-70.

48. Comninellis C, Nerini A (1995) Anodic oxidation of phenol in the presence of $\mathrm{NaCl}$ for wastewater treatment. Journal of applied electrochemistry 25(1): 23-28.

49. Tzedakis T, Savall A, Clifton MJ (1989) The electrochemical regeneration of Fenton's reagent in the hydroxylation of aromatic substrates: batch and continuous processes. Journal of applied electrochemistry 19(6): 911-921.

50. Sudoh M, Kodera T, Sakai K, Zhang JQ , koide K (1986) oxidative degradation of aqueous phenol effluent with electrogenerated fenton"s reagent. Journal of chemical engineering of japan 19(6): 513-518.

51. George W, Gokel D (2006) Handbook of organic chemistry. Walton, London, UK, pp. 676.

52. Xiao S, Qu J, Zhao X, Liu H, Wan D ( 2009) Electrochemical process combined with UV light irradiation for synergistic degradation of ammonia in chloride-containing solutions. Water Research 43(5): $1432-1440$

53. Li G, Qu J, Zhang X, Ge J (2006) Electrochemically assisted photo catalytic degradation of Acid Orange 7 with $\beta-\mathrm{PbO}_{2}$ electrodes modified by $\mathrm{TiO}_{2}$. Water Res 40(2): 213-220.

54. Arslan G, Yazici B, Erbil M (2005) The effect of pH, temperature and concentration on electrooxidation of phenol. Journal of hazardous materials 124(1): 37-43.

55. Rajkumar D, Song BJ, Kim JG (2007) Electrochemical degradation of Reactive Blue 19 in chloride medium for the treatment of textile dyeing wastewater with identification of intermediate compounds. Dyes and pigments 72(1): 1-7.

56. Thirugnanasambandham K, Sivakumar V, Prakash MJ ( 2014) Optimization of electro coagulation process to treat biologically pretreated bagasse effluent. Journal of the Serbian Chemical Society 79(5): 613-626.

57. Jadhav SB, Chougule AS, Shah DP, Pereira CS, Jadhav JP (2015) Application of response surface methodology for the optimization of textile effluent biodecolorization and its toxicity perspectives using plant toxicity, plasmid nicking assays. Clean Technologies and Environmental Policy 17(3): 709-720.

58. Gonder ZB, Kaya Y, Vergili I, Barlas H (2010) Optimization of filtration conditions for CIP wastewater treatment by nanofiltration process using Taguchi approach. Separation and purification tec hnology 70(3): 265-273.

59. Kasiri MB, Aleboyeh H, Aleboyeh A (2008) Modeling and optimization of heterogeneous photo-fenton process with response surface methodology and artificial neural networks. Environmental science \& technology 42(21): 7970-7975.

60. Torrades F, Garcia Hortal JA, Nunez L (2008) Fenton and photo-Fenton oxidation of a model mixture of dyes-overall kinetic analysis. Coloration Technology 124(6): 370-374.

61. Lopez Grimau V, Gutierrez MC (2006) Decolourisation of simulated reactive dye bath effluents by electrochemical oxidation assisted by UV light. Chemosphere 62(1): 106-112.

62. Sala M, Del Rio AI, Molina J, Cases F, Gutierrez Bouzan MC (2012) Influence of cell design and electrode materials on the decolouration of dyeing effluents. Int J Electrochem Sci 7: 12470-12488.

63. Serikawa RM, Isaka M, Su Q, Usui T, Nishimura T, et al. (2000) Wet electrolytic oxidation of organic pollutants in wastewater treatment. Journal of applied electrochemistry 30(7): 875-883.

64. Derringer G (1980) Simultaneous optimization of several response variables. Journal of quality technology 12(4): 214-219.

65. Bezerra MA, Santelli RE, Oliveira EP, Villar LS, Escaleira LA ( 2008) Response surface methodology (RSM) as a tool for optimization in analytical chemistry. Talanta 76(5): 965-977.

66. Abu Hassan MA, pei li T, Zain on Noor Z (2004) Coagulation and flocculation treatment of wastewater in chicken processing industry using chitosan. J Chem Nat Resour Eng 4(1): 43-53.

67. Fockedey E, Van Lierde A (2002) Coupling of anodic and cathodic reactions for phenol electro-oxidation using three-dimensional electrodes. Water research 36(16): 4169-4175.

68. Zhou M, He J (2008) Degradation of cationic red X-GRL by electrochemical oxidation on modified $\mathrm{PbO}_{2}$ electrode. Journal of hazardous materials 153(1): 357-363. 
This work is licensed under Creative Commons Attribution 4.0 Licens

DOI: 10.19080/IJESNR.2017.02.555583
Your next submission with Juniper Publishers will reach you the below assets

- Quality Editorial service

- Swift Peer Review

- Reprints availability

- E-prints Service

- Manuscript Podcast for convenient understanding

- Global attainment for your research

- Manuscript accessibility in different formats ( Pdf, E-pub, Full Text, Audio)

- Unceasing customer service

Track the below URL for one-step submission https://juniperpublishers.com/online-submission.php 